\title{
Phylogenetic relationships and generic reassessment of Proustia and allies (Compositae: Nassauvieae)
}

\author{
Gisela Sancho, ${ }^{1}$ Liliana Katinas, ${ }^{1}$ Jessica N. Viera Barreto, ${ }^{1}$ Andrés Moreira-Muñoz ${ }^{2} \&$ Federico Luebert ${ }^{3,4,5}$ \\ 1 División Plantas Vasculares, Museo de La Plata, Paseo del Bosque s.n., La Plata, Argentina \\ 2 Pontificia Universidad Católica de Valparaíso, Av. Brasil 2241, Valparaíso, Chile \\ 3 Institut für Biologie - Botanik, Freie Universität Berlin, Altensteinstr. 6, 14195 Berlin, Germany \\ 4 Nees-Institut für Biodiversität der Pflanzen, Universität Bonn, Meckenheimer Allee 170, 53115 Bonn, Germany \\ 5 Departamento de Silvicultura, Facultad de Ciencias Forestales, Universidad de Chile, Santiago, Chile \\ Author for correspondence: Federico Luebert,fluebert@uni-bonn.de
}

DOI https://doi.org/10.12705/671.7

\begin{abstract}
Proustia is a small southern Andean genus of shrubs, vines and small trees, which are characteristic elements of Chilean and Argentine Andean forests, thickets and desert scrubs. Since Proustia possesses an unusual and characteristic morphology within the Nassauvieae, its circumscription as well as its phylogenetic placement is decisive in understanding the evolution of the tribe. Berylsimpsonia, from the Caribbean, was segregated from Proustia, which currently only includes three species. Lophopappus, another Andean genus, has been closely related to Proustia in sharing style and corolla features that are unusual in the Nassauvieae. The purpose of this work is to evaluate the placement of Proustia within the Nassauvieae, its relationships with Berylsimpsonia and Lophopappus, and the relationships of its species using molecular data and phylogenetic methods. This is the first comprehensive analysis of Proustia. We have included in our study the three currently accepted species of Proustia and seven of its ten infraspecific taxa. For each taxon of Proustia, one to seven accessions were analyzed. Species of Lophopappus and Berylsimpsonia, as well as 16 species belonging to 13 genera of Nassauvieae were also analyzed. We sequenced the nuclear ribosomal ITS and ETS, and the plastid regions $n d h F, 5^{\prime} \operatorname{trnK}-m a t K, \operatorname{trnL-trnF}$, and $\operatorname{trn} L(U A G)$-rpl32. Unlike other previous studies, Proustia is not sister to the rest but nested in the tribe in our analyses. Berylsimpsonia vanillosma and P. ilicifolia are distantly related to $P$. pyrifolia, the type of the genus. According to nuclear DNA data, the infraspecific taxa of $P$. cuneifolia were recovered all in a well-supported clade, although based on the plastid data P. pyrifolia does not form a lineage separate from P. cuneifolia. Lophopappus is the genus most closely related to Proustia. Regarding the evolution of styles, our results suggest multiple origins of atypical stylar features in the Nassauvieae. As a result of our analyses we propose the segregation of Proustia ilicifolia into the new genus Spinoliva. Morphological data are consistent with the segregation of Proustia and Lophopappus as separate genera. Two species of Proustia, P. cuneifolia and P. pyrifolia are recognized. Three lectotypifications, one neotypification, two new combinations and five rank changes are proposed.
\end{abstract}

Keywords Andes; Berylsimpsonia; Lophopappus; molecular phylogeny; South America

Supplementary Material DNA sequence alignments are available from https://doi.org/10.12705/671.7.S

\section{INTRODUCTION}

The Compositae are the largest family of flowering plants and a key element to understand biodiversity globally (Funk \& al., 2009; Willis, 2017). Proustia Lag. is a small intriguing Andean genus of the Compositae, which belongs to the tribe Nassauvieae within the subfamily Mutisioideae. Proustia occurs from Peru to Central Chile and Argentina. Its species are characteristic elements of sclerophyllous Andean forests, thickets and desert scrubs (Cabrera, 1971; Luebert \& Pliscoff, 2006). After the Barnadesioideae and Famatinanthoideae, the subfamily Mutisioideae is the sister group to the remaining over $95 \%$ of the species of Compositae (Panero \& al., 2014). Therefore, understanding the relationships of genera like Proustia is crucial in helping to elucidate the early evolution of this family.
While Proustia has long been placed in Nassauvieae based on its predominantly bilabiate corollas, tailed anthers and pollen exine stratification (e.g., Crisci, 1974; Cabrera, 1977; Tellería \& al., 2003; Katinas \& al., 2008a, b), its placement within this tribe is not yet clear. In previous phylogenetic analyses, Proustia was recovered as sister to the rest of Nassauvieae (Panero \& Funk, 2008), whereas in other studies its placement was variable and even dependent on which molecular markers were employed (Katinas \& al., 2008b; Luebert \& al., 2009; Simpson \& al., 2009; Jara-Arancio \& al., 2017). However, these studies did not focus on Proustia and each of them included only one of its three species. Because it possesses atypical morphological features, the circumscription of Proustia, as well as its phylogenetic placement in the Nassauvieae, are decisive to understand the evolution of the tribe. Proustia differs from the core of the tribe by its apically rounded style branches (Crisci,

Article history: Received: 4 Aug 2017 | returned for (first) revision: 26 Sep 2017 | (last) revision received: 5 Dec 2017 | accepted: 6 Dec 2017 | published: online fast track, n/a; in print and online issues, 6 Mar 2018 || Associate Editor: Alfonso Susanna || C) International Association for Plant Taxonomy (IAPT) 2018, all rights reserved 

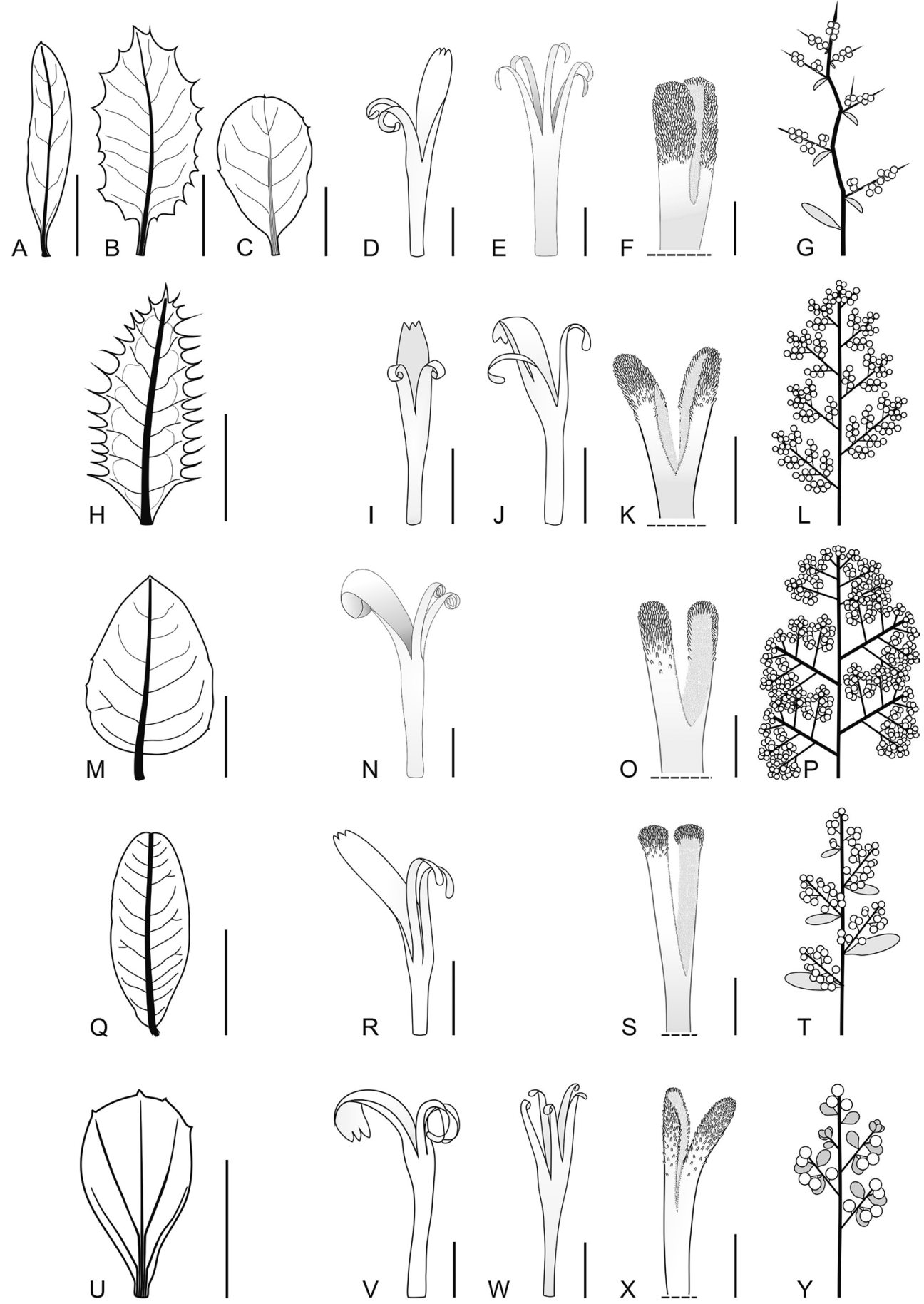

Fig. 1. Morphological distinctive characters of Proustia and related genera. A-G, P. cuneifolia: A-C, Leaf blades with pinnate venation showing shape and margin variation; A, P. cuneifolia f. cuneifolia (Sancho \& al. 262, LP); B, P. cuneifolia f. mendocina (Böcher \& al. 2268, LP); C, P. cuneifolia f. tipia (Niemeyer s.n., LP); D, Bilabiate corolla (Rodríguez 1435, LP); E, Deeply 5-lobed corolla (Rodríguez 1435, LP); F, Style (Ferreyra 13939, LP); G, Representation of capitulescence showing thorny axes. H-L, P. ilicifolia: H, Leaf blade showing pinnate venation (Wedermann 423, F); I, Bilabiate corolla (Coquimbo, Paihuano, 5 Feb 1883, without collector, s.n., LP); J, Sub-bilabiate corolla (Coquimbo, Paihuano, 5 Feb 1883, without collector, s.n., LP); K, Style (Ricardi 5553, LP); L, Representation of unarmed capitulescence. M-P, P. pyrifolia: M, Leaf blade showing pinnate venation (Sancho \& al. 291, LP); N, Bilabiate corolla (Lourteig 2514, LP); O, Style (Lourteig 2514, LP); P, Representation of capitulescence. Q-T, Berylsimpsonia vanillosma: Q, Leaf blade showing pinnate venation (Ekman 3034, LP); R, Bilabiate corolla (Ekman 4306, LP); S, Style (Ekman 4306, LP); T, Representation of capitulescence. U-Y, Lophopappus tarapacanus: U, Leaf blade showing acrodromous venation (Tovar 1386, LP); V, Bilabiate corolla (Heins 231, LP); W, Deeply 5-lobed corolla (Tovar 1386, LP); X, Style (Heins 231, LP); Y, Representation of capitulescence and stem branches with brachyblasts. - White circles represent capitula, grey structures represent leaves. Scale bars: A, B, $\mathrm{H}, \mathrm{M} \& \mathrm{Q}=2 \mathrm{~cm} ; \mathrm{C}=6 \mathrm{~mm} ; \mathrm{D}, \mathrm{E}, \mathrm{I}, \mathrm{J}, \mathrm{N}, \mathrm{R}, \mathrm{V} \& \mathrm{~W}=2 \mathrm{~mm} ; \mathrm{F}, \mathrm{K}, \mathrm{O}, \mathrm{S} \& \mathrm{X}=0.5 \mathrm{~mm} ; \mathrm{U}=1 \mathrm{~cm}$. Note: Proustia pyrifolia occasionally has corollas deeply 5-lobed (Crisci, 1974). However, we failed to find this type of corolla. Drawn by Gisela Sancho. 
1974; Sancho \& al., 2014), dorsally covered by collecting hairs on the distal half (vs. usually apically truncate style branches with an apical tuft of collecting hairs in most Nassauvieae). In addition, the corollas of Proustia are sometimes deeply 5-lobed (Fig. 1) instead of the typical bilabiate corollas of Nassauvieae.

Intergeneric relationships of Proustia are no less problematic. Lophopappus Rusby, an Andean genus of five species (Katinas \& al., 2013) has been closely related to Proustia, mainly by sharing style, corolla, and pollen features (Crisci, 1974; Tellería \& al., 2003; Katinas \& al., 2013; Sancho \& al., 2014). Figures 1A-P and U-Y show some of their distinctive features. Lophopappus and Proustia were synonymized by Ferreyra (1995) and have been recovered as sister groups in previous phylogenetic analyses (Panero \& Funk, 2008). Proustia was considered to be composed of four species by Fabris (1968). Based on differences of morphological characters, one of the species included in Proustia by Fabris (1968), P. vanillosma C.Wright from the Caribbean, was transferred first to Acourtia D.Don (Crisci, 1974) and then to the new genus Berylsimpsonia B.L.Turner (Turner, 1993) (Fig. 1Q-T), bringing Proustia to its present circumscription with three species. Until now, the phylogenetic relationships between Berylsimpsonia, Lophopappus and Proustia remained unstudied with molecular data.

Although it only includes three species (Fabris, 1968; Sancho \& al., 2014) (Table 1), Proustia shows a highly variable morphology, and this variation led Fabris (1968) to recognize several forms under each species. Besides, recent morphological phylogenetic analyses have challenged its monophyly (Sancho $\&$ al., 2014). If Proustia is confirmed as non-monophyletic, the systematic and evolutionary significance of its unusual morphological characters mentioned above would need to be re-evaluated within Nassauvieae.

A non-monophyletic Proustia could explain its variable morphology despite the low number of species (Sancho \& al., 2014). Indeed, homology of some of the traditional diagnostic features of Proustia is under debate. Sancho \& al. (2014) indicated that the spiny structures usually referred to as diagnostic of Proustia are not homologous and probably adaptations to particular habitats. Spiny structures and secondary inflorescences (capitulescences) support independent lineages each representing one species of Proustia (Table 1; Figs. 1, 2). These findings seem to agree with previous authors who subdivided Proustia into different sections, with one species each (Don, 1830; Candolle, 1838; Fabris, 1968). The monophyly of Proustia and the interspecific relationships have not yet been addressed in molecular phylogenetic studies.

The purpose of this work was to evaluate the placement of Proustia within the Nassauvieae, its relationships with Berylsimpsonia and Lophopappus, and the relationships of its species using molecular data and phylogenetic methods. Since our results confirmed the non-monophyly of Proustia, we offer a reinterpretation of homology of morphological characters traditionally used to define Proustia and provide generic rearrangements necessary to accommodate monophyletic groups into taxonomic entities.

\section{口 MATERIALS AND METHODS}

Taxon sampling. - We included the three accepted species of Proustia and seven of its ten infraspecific taxa recognized by Fabris (1968) (Appendix 1). Under the synonymy proposed herein (Table 1), all the infraspecific taxa were sampled. For each taxon of Proustia, one to seven accessions were analyzed. Three species (of five) of Lophopappus and one (of two) species of Berylsimpsonia were included as closely related taxa of Proustia (e.g., Fabris, 1968; Crisci, 1974; Luebert \& al., 2009). Nassauvieae possesses 25 genera and around 320 species (Katinas \& al., 2008a). Twenty-two species belonging to 13 genera of Nassauvieae (Acourtia, Calopappus Meyen, Dolichlasium Lag., Holocheilus Cass., Jungia L.f., Leucheria Lag., Moscharia Ruiz \& Pav., Nassauvia Comm. \& Juss., Oxyphyllum Phil.,

Table 1. Proustia sections, species and forms (according to Fabris, 1968 and Cabrera, 1977), diagnostic characters of sections.

\begin{tabular}{|c|c|c|c|c|}
\hline Section & Diagnostic characters & Species & Infraspecific taxa & Taxonomy proposed here \\
\hline $\begin{array}{l}\text { Baccharoides } \\
\text { DC. }\end{array}$ & $\begin{array}{l}\text { Erect shrubs; branches } \\
\text { unarmed (without thorns } \\
\text { or spines); leaf margin } \\
\text { spiny; capitula arranged } \\
\text { in thyrses }\end{array}$ & $\begin{array}{l}\text { P. ilicifolia } \\
\text { Hook. \& Arn. }\end{array}$ & $\begin{array}{l}\text { f. baccharoides (Hook. \& Arn.) } \\
\text { Fabris } \\
\text { f. ilicifolia }\end{array}$ & $\begin{array}{l}\text { 三 Spinoliva ilicifolia subsp. baccharoides (D.Don) } \\
\text { G.Sancho } \\
\text { Spinoliva ilicifolia (Hook. \& Arn.) G.Sancho } \\
\text { subsp. ilicifolia }\end{array}$ \\
\hline $\begin{array}{l}\text { Harmodia } \\
\text { D.Don }\end{array}$ & $\begin{array}{l}\text { Erect shrubs; inflores- } \\
\text { cence axes distally spiny } \\
\text { (thorns); capitula arranged } \\
\text { in racemes of spikes or } \\
\text { glomerules }\end{array}$ & $\begin{array}{l}\text { P. cuneifolia } \\
\text { D.Don }\end{array}$ & $\begin{array}{l}\text { f. angustifolia (Wedd.) Fabris } \\
\text { f. cinerea (Phil.) Fabris } \\
\text { f. cuneifolia } \\
\text { f. mendocina (Phil.) Fabris } \\
\text { var. mollis (Kuntze) Cabrera } \\
\text { f. oblongifolia (Wedd.) Fabris } \\
\text { f. tipia (Phil.) Fabris }\end{array}$ & $\begin{array}{l}=\text { subsp. mollis (Kuntze) Katinas } \\
\equiv \text { subsp. cinerea (Phil.) Luebert } \\
\text { subsp. cunefolia } \\
\equiv \text { subsp. mendocina (Phil.) Katinas } \\
\equiv \text { subsp. mollis (Kuntze) Katinas } \\
=\text { subsp. cuneifolia } \\
\equiv \text { subsp. tipia (Phil.) Luebert }\end{array}$ \\
\hline Proustia & $\begin{array}{l}\text { Scandent shrubs; branches } \\
\text { with infrapetiolar spines; } \\
\text { capitula arranged in glo- } \\
\text { merulose thyrses }\end{array}$ & $\begin{array}{l}\text { P. vanillosma } \\
\text { C.Wright } \\
\text { P. pyrifolia } \text { DC. }\end{array}$ & $\begin{array}{l}\text { f. glandulosa (DC.) Fabris } \\
\text { f. pyrifolia }\end{array}$ & $\begin{aligned} & \text { Berylsimpsonia vanillosma (C.Wright) B.L.Turner } \\
= & \text { Proustia pyrifolia }\end{aligned}$ \\
\hline
\end{tabular}

Proustia vanillosma is currently a species of the genus Berylsimpsonia B.L.Turner. 
Perezia Lag., Polyachyrus Lag., Triptilion Ruiz \& Pav., Trixis P.Browne) were also analyzed. Representatives of Mutisieae (species of Adenocaulon Hook., Chaetanthera Ruiz \& Pav., Gerbera L., Mutisia L.f., Pachylaena Hook.) and Onoserideae (Gypothamnium Phil., Plazia Ruiz \& Pav., Urmenetea Phil.) were included as more distantly related outgroups. We rooted the trees with one representative of Barnadesioideae (Chuquiraga Juss.), which is sister to all remaining Compositae. Available Proustia and outgroup sequences (57) were obtained from GenBank (Appendix 1), provided by Katinas \& al. (2008b), Panero \& Funk (2008), Luebert \& al. (2009), Simpson \& al. (2009), Pelser \& al. (2010), Panero \& al. (2014) and Chacón \& al. (2017).
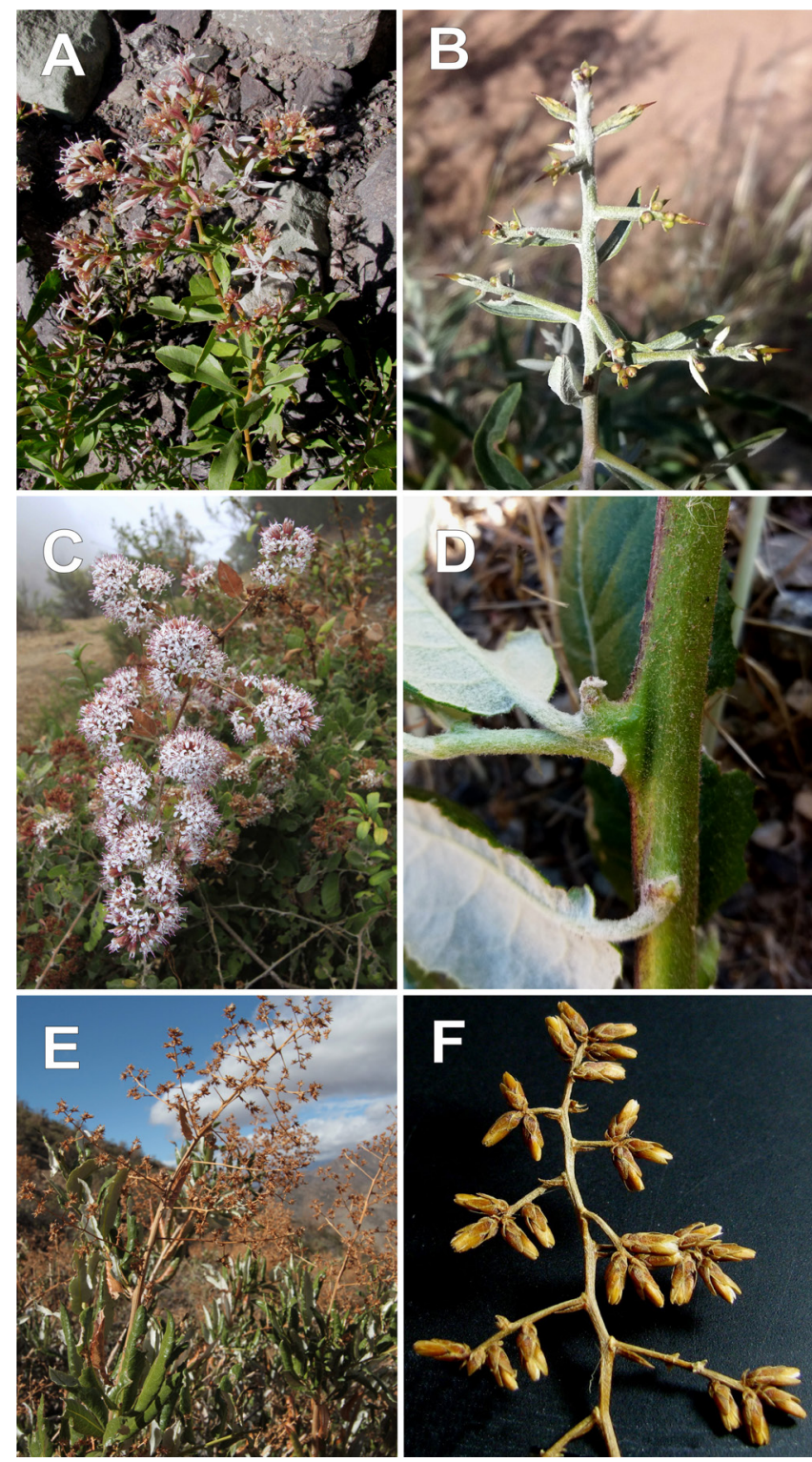

Fig. 2. A \& B, Proustia cuneifolia f. cuneifolia: A, Capitulescence; B, Detail of capitulescence showing thorns. C \& D, P. pyrifolia: C, Capitulescence; D, Infrapetiolar spine. E \& F, P. ilicifolia: E, Capitulescence; F, Detail of unarmed capitulescence. - Photos: A, B, D \& F, G. Sancho; C \& E, A. Moreira-Muñoz.
DNA isolation, amplification, and sequencing. - Genomic DNA was extracted from leaf material (dried in silica gel or from herbarium specimens) using a modified CTAB method (Doyle \& Dickson, 1987), DNeasy plant mini kit (Qiagen, Valencia, California, U.S.A.) or Nucleospin Plant II Kit (MachereyNagel, Düren, Germany) following manufacturer's instructions. We sequenced the nuclear ribosomal ITS and ETS, and the plastid regions $\operatorname{trnL}-\operatorname{trnF}, 5^{\prime} \operatorname{trnK}$-matK, $\operatorname{trnL}(U A G)-r p l 32$ and $n d h F$. PCR reaction mixes for all markers were $12-13 \mu \mathrm{l}$ $\mathrm{ddH}_{2} \mathrm{O}, 1 \mu \mathrm{l}$ DNA, $2.5 \mu \mathrm{l}$ type $10 \times$ buffer, $2.5 \mu \mathrm{l} 25 \mathrm{mM}$ dNTPs, 1.5-2.5 $\mu \mathrm{l}$ of each $10 \mu \mathrm{M}$ primer, $1.5 \mu \mathrm{l} 25 \mathrm{mM} \mathrm{MgCl}_{2}$, and 0.2 or $0.4 \mu \mathrm{l}$ of Invitrogen (Life Technologies, São Paulo, Brazil) Taq polymerase. All $25-\mu \mathrm{l}$ PCR reactions were performed in a Gene Prothermal cycler (Bioer Technology, Hangzhou, Japan-China) or Trio-Thermoblock thermal cycler (Biometra, Göttingen, Germany). Amplification primers for ITS were those of White \& al. (1990) and cycling conditions followed Katinas \& al. (2008a). The ETS was amplified with primers ETS1 and 18S-IGS (Baldwin \& Markos, 1998 and Bayer \& al., 2002, respectively) and cycling conditions followed Sancho \& al. (2015). Amplification primers c and f for $\operatorname{trnL}-\operatorname{trn} F$ were those of Taberlet \& al. (1991) and cycling conditions followed Katinas \& al. (2008a). The 5' trnK-matK was amplified with primers 3914F (Johnson \& Soltis, 1994) and 1240R (Bayer \& al., 2002) and cycling conditions followed Sancho \& al. (2015). The $\operatorname{trn} L(U A G)$-rpl32 region was amplified with primers rpl32 and trnL (Shaw \& al., 2007) with cycling conditions following Baird \& al. (2010). Amplification primers for $n d h F$ were $1 \mathrm{~F}$, 1318R, 972F (Olmstead \& Sweere, 1994) and +607 (Kim \& Jansen, 1995) and cycling conditions followed Kim \& Jansen (1995). The PCR products were purified using a QIAquick purification kit (Quiagen) or GeneJET PCR Purification Kit (Thermo Fisher Scientific Biosciences, St. Leon-Rot, Germany) following the manufacturer's instructions. Cycle sequencing was performed with BigDye Terminator v.3.1 and sequenced on an ABI 3730xl DNA Analyzer (Applied Biosystems, Foster City, California, U.S.A.). Contig building of resulting sequences was carried out using Geneious Pro v.5.6.5 (Biomatters, Auckland, New Zealand) and aligned using the software MAFFT v.6.603 (Katoh \& al., 2002) followed by manual adjustments using PhyDE v.0.9971 (available from http://www.phyde.de/, accessed 17 Apr 2014) and BioEdit v.7.2.6 (Ibis Biosciences, Carlsbad, California, U.S.A.). The 233 newly generated sequences were deposited in GenBank (Appendix 1).

Phylogenetic analyses. - Nuclear (ETS, ITS) and plastid data ( $n d h F, 5^{\prime}$ trnK, trnL-trnF, trnL(UAG)-rpl32) were analyzed separately. The topologies of separate ITS and ETS analyses were checked for congruence before combining them. The nuclear dataset contained 58 accessions and 28\% missing data, mostly because we were unable to amplify ITS in several Proustia species or because only one of the markers was available from the literature. The plastid dataset contained 56 accessions and 9\% missing data (see Appendix 1).

Maximum likelihood (ML; Felsenstein, 1981) and Bayesian (BA; Mau \& al., 1999) analyses were carried out for each data matrix on the CIPRES Science Gateway (Miller \& al., 2010). ML analyses were conducted in RAxML v.8.2.10 (Stamatakis 
$\&$ al., 2008) and BA was performed using MrBayes v.3.2.6 (Ronquist \& Huelsenbeck, 2003). Partitions were unlinked in both analyses. The software jModelTest v.2.1.2 (Darriba \& al., 2012), under the Akaike information criterion (AIC), was used to determine the substitution model that best fitted sequence data of each data partition.

Bootstrap support (BS) was calculated in the ML based on 1000 replicates. For BA, analyses were conducted in 4 independent runs for 2 million generations sampling every 1000 generations. The first 500 trees $(25 \%)$ were discarded as burn-in after checking for convergence in Tracer v.1.5 (available at http://tree. bio.ed.ac.uk/software/tracer/, accessed 15 Oct 2012), that ESS values of all parameters lay above 200 . Posterior probabilities (PP) at nodes correspond to the $50 \%$ majority-rule consensus tree calculated from of the posterior distribution of the BA.

Topology tests. - We conducted topology tests in order to assess the plausibility of alternative topologies given our datasets. The original topology retrieved from the ML analyses of the nuclear and plastid datasets were modified using TreeGraph v.2.7.0-557-beta (Stöver \& Müller, 2010) to obtain the following alternative topologies: (1) Proustia ilicifolia sister to Lophopappus + P. cuneifolia + P. pyrifolia, (2) Proustia ilicifolia sister to P. cuneifolia + P. pyrifolia, (3) Proustia ilicifolia sister to P. cuneifolia, (4) Proustia pyrifolia sister to P. cuneifolia. The approximately unbiased test (AU-test; Shimodaira, 2002) was employed to test all alternative topologies against the respective original topology. We used the IQ-TREE software v.1.5.5-beta (Nguyen \& al., 2015) and analyses were run with 10,000 bootstrap replicates.

Morphological observations. - For the taxonomic treatment, the specimens studied are those indicated in Sancho \& al. (2014). Additionally, specimens housed at B, K, P, S and SGO were analyzed. Type specimens were examined during research visits to herbaria or from herbarium websites. Pollen terminology follows Punt \& al. (1994).

\section{RESULTS}

Phylogenetic analyses. - Our nuclear dataset had a total of 1321 aligned positions (ETS: 570, ITS: 751) and 995 distinct alignment patterns (ETS: 446, ITS: 549). Substitution model $\mathrm{GTR}+\Gamma$ was selected for ETS and GTR $+\mathrm{I}+\Gamma$ for ITS. ML and BA analyses yielded identical trees, with differences only in the support of some branches. Figure 3A shows the topology of the ML analysis using nrDNA data.

Our plastid dataset had a total of 5402 aligned positions (ndhF: 2172, 5' trnK-matK: 1133, trnL-trnF: 978, trnL(UAG)rpl32: 1119) and 1473 distinct alignment patterns (ndhF: 438, 5' trnK-matK: 275, trnL-trnF: 325, $\operatorname{trnL}(U A G)$-rpl32: 435). Substitution model HKY $+\Gamma$ was selected for $\operatorname{trnL}-\operatorname{trn} F$ and GTR $+\Gamma$ for $n d h F, 5^{\prime} \operatorname{trnK}-m a t K$ and $\operatorname{trnL}(U A G)-r p l 32$. ML and BA analyses yielded similar trees, with differences only in the support of some branches. Figure 3B shows the topology of the BA analysis using plastid data.

The results obtained from the nuclear and plastid data both suggest that Berylsimpsonia, Trixis, Dolichlasium and
Jungia form a monophyletic group. Moreover, Proustia ilicifolia, P. pyrifolia and Lophopappus were each retrieved as well-supported monophyletic groups in both nuclear and plastid trees. Furthermore, the results of both nuclear and plastid datasets suggest that Lophopappus, Proustia cuneifolia and P. pyrifolia form a well-supported monophyletic group. Conversely, the topologies obtained from nuclear and plastid data differ in two major aspects. First, in the nuclear tree $P$. pyrifolia was retrieved as sister to Lophopappus $(\mathrm{PP}=1, \mathrm{BS}=88)$, while in the plastid tree $P$. pyrifolia was recovered as sister to $P$. $c u$ neifolia f. mendocina ( $\mathrm{PP}=1, \mathrm{BS}=99)$. Second, $P$. ilicifolia was recovered as sister to all remaining Nassauvieae except Leucheria, Moscharia, Oxyphyllum and Polyachyrus in the nuclear tree, whereas in the plastid tree P. ilicifolia is sister to the latter four genera. However, the relationships of $P$. ilicifolia are only weakly supported in both analyses. Given the lack of topological congruence between nuclear and plastid trees, we did not combine these datasets.

Topology tests. - The results of the AU-test suggest that all alternative topologies should be rejected (Fig. 4). Neither Proustia ilicifolia sister to Lophopappus + P. cuneifolia + P. pyrifolia nor sister to $P$. cuneifolia or to P. cuneifolia $+P$. pyrifolia are as good explanations of the datasets as the original topologies obtained both from the nuclear and plastid datasets. The only exception occurs when $P$. pyrifolia is made sister to $P$. cuneifolia, which is rejected only as an explanation of the plastid dataset, but not of the nuclear dataset.

\section{- DISCUSSION}

Phylogenetic relationships of Proustia in Nassauvieae. This is the first comprehensive analysis of Proustia, a small but highly variable genus of Nassauvieae with unusual morphology. Unlike previous studies, in our analyses with nuclear data Proustia is not sister to the rest but nested in the tribe, albeit with low support. This contrasts with the results of Panero \& Funk (2008) and Panero \& al. (2014), but agrees with other studies (Katinas \& al., 2008b; Luebert \& al., 2009).

Two species formerly included in Proustia, P. ilicifolia and $P$. vanillosma (the latter currently Berylsimpsonia vanillosma) are distantly related to $P$. pyrifolia, the type of the genus. However, the placement of $P$. ilicifolia was uncertain in our phylogenetic trees and varied depending on whether plastid or nuclear data were taken into account. Only one previous phylogenetic study had included P. ilicifolia (Jara-Arancio \& al., 2017), retrieving it as sister to Macrachaenium Hook.f. We were not able to include Macrachaenium in our analysis. The placement of Macrachaenium remains uncertain within the Mutisioideae and necessitates further analyses. Berylsimpsonia was retrieved as closely related to Trixis, as suggested by Turner (1993). However, these relationships were not recovered in previous phylogenetic analyses based on morphological data (Crisci, 1974; Sancho \& al., 2014).

According to our nuclear DNA data, the infraspecific taxa of $P$. cuneifolia are all included in a well-supported clade in agreement with classifications of previous authors (Cabrera, 


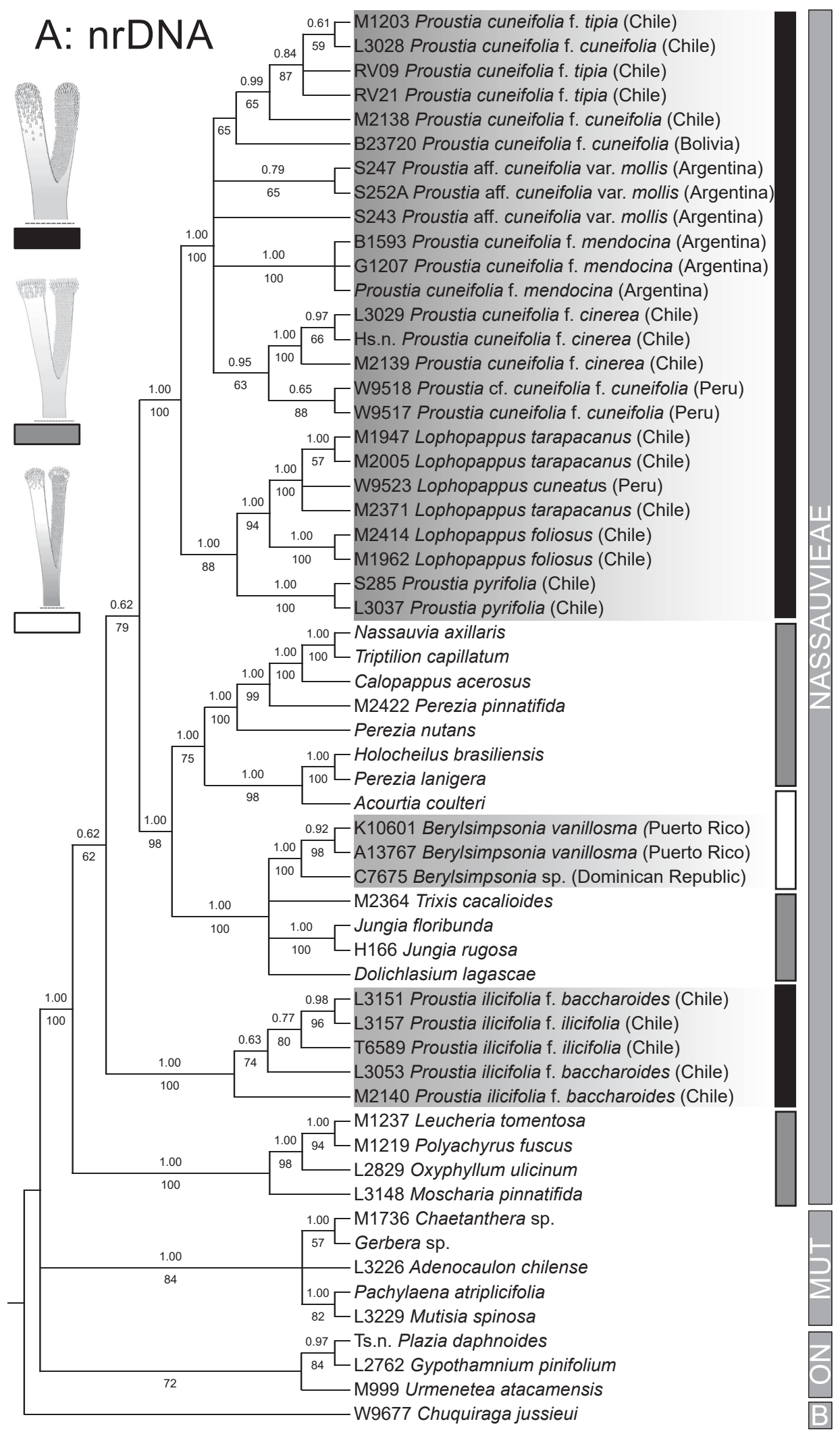

Fig. 3. ML trees obtained in the analyses with Bayesian posterior probabilities $>0.5$ above branches and ML bootstrap values $>50$ below branches. Nodes with $<50 \%$ ML bootstrap support were collapsed to polytomies. Highlighted clades correspond to the genera Proustia, Lophopappus and Berylsimpsonia. Before taxon names of accessions sequenced in this study are the initial of the senior collector's last name and the collection number as indicated in Appendix 1. A, Tree obtained from nrDNA data; B, Tree obtained from plastid DNA data. — Major clades are indicated: 


\section{B: cpDNA}
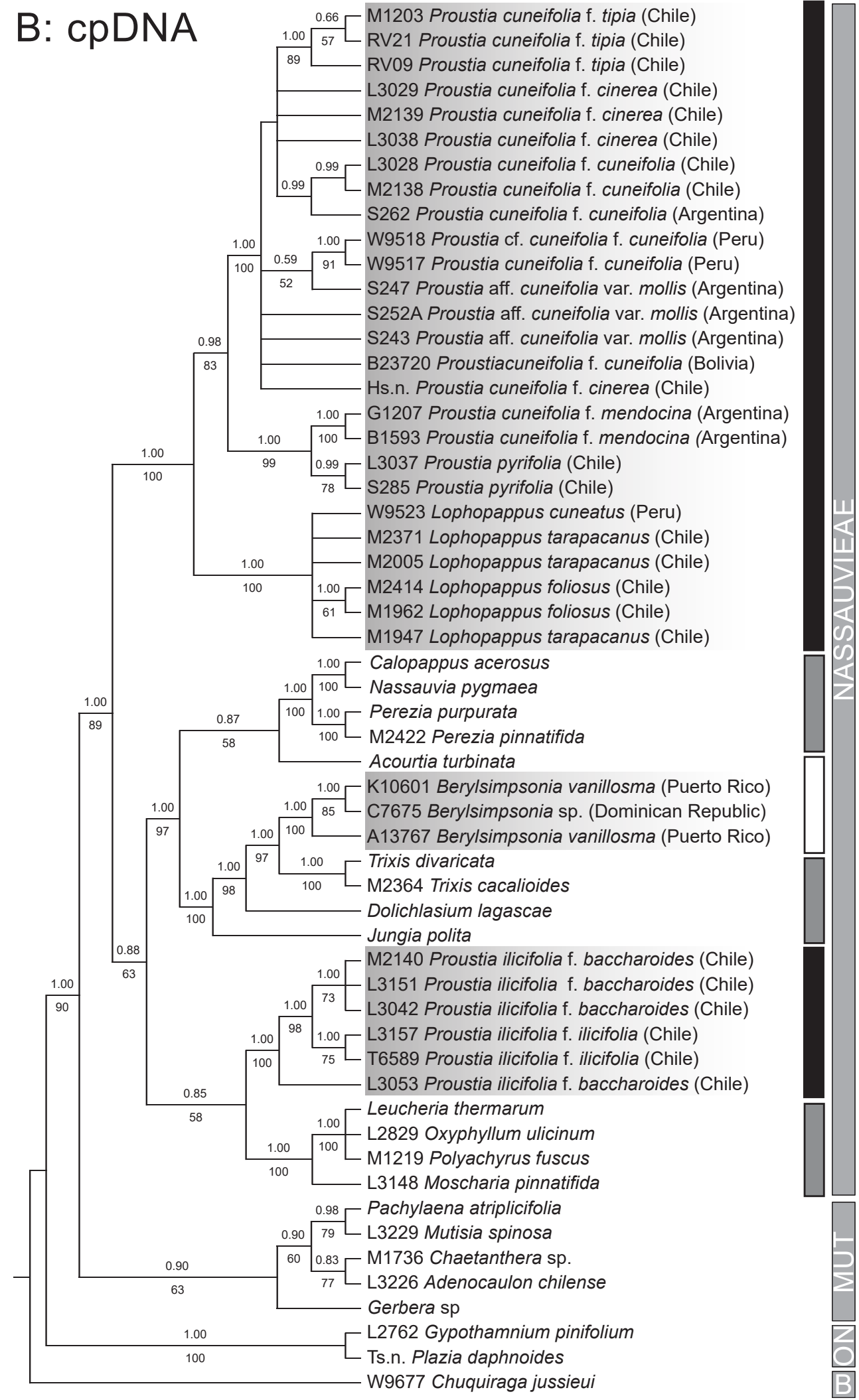

MUT, Mutisieae; ON; Onoserideae; B, Barnadesioideae (outgroup). Drawings and bars besides taxon names represent the types of styles of Nassauvieae; black bar: style bilobed, branches relatively short, apically rounded and dorsally hairy in distal half, atypical of Nassauvieae; white bar: style bifid, with flattened and truncate branches, dorsally glabrous and crowned with a tuft of elongate collecting hairs, typical of Nassauvieae; grey bar: style bifid, branches relatively long, apically rounded and slightly expanded, dorsally hairy in distal fifth, atypical of Nassauvieae. 
1953; Fabris, 1968). However, our plastid data suggest $P$. pyrifolia is sister to P. cuneifolia f. mendocina. Although a placement of $P$. pyrifolia as sister to $P$. cuneifolia cannot be rejected as a good explanation of our nuclear data (Fig. 4), a hybrid origin of $P$. pyrifolia as a cause for its discordant position in nuclear and plastid trees cannot be ruled out (Degnan \& Rosenberg, 2009). This possibility should be further explored. However, the current distributions of $P$. pyrifolia, P. cuneifolia f. mendocina and Lophopappus do not overlap and no morphological characters known to us seem to support an hybrid origin.

Lophopappus is recovered as the most closely related taxon to Proustia (excl. P. ilicifolia) in all analyses, a result that confirms previous analyses with morphological (Crisci, 1974, 1980; Katinas, 1994) and molecular data (Panero \& Funk, 2008; Luebert \& al., 2009). These studies highlight that the most important morphological characters are those of the style and the corolla.

The unusual styles and corollas of Proustia in the context of Nassauvieae. - In Compositae, style morphology is not only crucial in the context of secondary pollen presentation mechanisms, but contributed important characters to tribal circumscription (Erbar \& Leins, 2015; Katinas \& al., 2016).

Typically defined as bifid, with flattened and truncate branches, dorsally glabrous and crowned with a tuft of elongate collecting hairs (style type 1; Crisci, 1974), the styles of Nassauvieae are distinctive for the tribe (Fig. 3). Indeed, a deeper analysis of stylar characteristics led Erbar \& Leins (2015) to identify two sub-types of styles within the usually regarded as "typical styles" of Nassauvieae.

Some genera, however, depart from these typical characteristics. For instance, styles with relatively short branches, apically rounded and dorsally hairy in distal half are atypical for the tribe and are found only in Proustia (P. cuneifolia, P. ilicifolia, P. pyrifolia; Fig. 1F, K, O), Cephalopappus Nees $\&$ Mart., Lophopappus (Fig. 1X) and Macrachaenium (style type 2 according to Crisci, 1974; Proustia type according to Erbar \& Leins, 2015). Another type of style with long, apically expanded branches, dorsally hairy on distal fifth, occurs in Acourtia, Leunisia Phil., Berylsimpsonia (Fig. 1S) and two species of Perezia (style type 3; Crisci, 1974). Neither Leunisia nor the two species of Perezia were included in our phylogenetic analyses.

This stylar morphological variability in Nassauvieae is unusual. Among the early-branching groups of Compositae, just Barnadesioideae and Nassauvieae have several style types (Erbar \& Leins, 2015).

Although we did not include all genera of Nassauvieae in our analyses, some observations about the evolution of the styles in this tribe can be outlined. As indicated above, stylar similarities shared by Berylsimpsonia and Acourtia were highlighted by Crisci (1974). In fact, Berylsimpsonia vanillosma (previously Proustia vanillosma; Fabris, 1968) was first transferred to Acourtia because of its style and pollen characteristics (Crisci, 1974). However, our results show that these two genera are not closely related, and their similar style features appear to have evolved twice independently (Fig. 3).

The same can be said about the styles of Proustia and the other genera mentioned above with branches relatively short, apically rounded and dorsally hairy on distal half. However, our analyses show that P. ilicifolia is distantly related to the other species of Proustia and Lophopappus despite all having similar stylar characteristics (Fig. 3). In consequence, our results suggest multiple origins of atypical stylar features in the Nassauvieae (Fig. 3), in agreement with Sancho \& al. (2014). The evolution of the unusual disk corollas of Proustia within Nassauvieae may have taken similar paths to those of style evolution. Disk corollas of Nassauvieae are typically bilabiate usually with a shallowly 3-lobed external lip and a deeply 2-lobed internal lip (Crisci, 1974; Katinas \& al., 2008a) (Fig. $1 \mathrm{D}, \mathrm{I}, \mathrm{N}, \mathrm{R}, \mathrm{V})$. As with styles, exceptions to the typical pattern

\section{A: nrDNA}
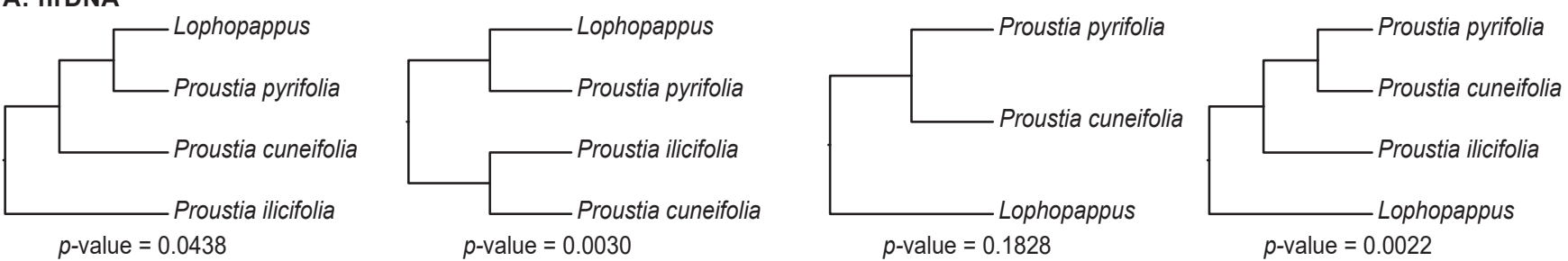

B: cpDNA
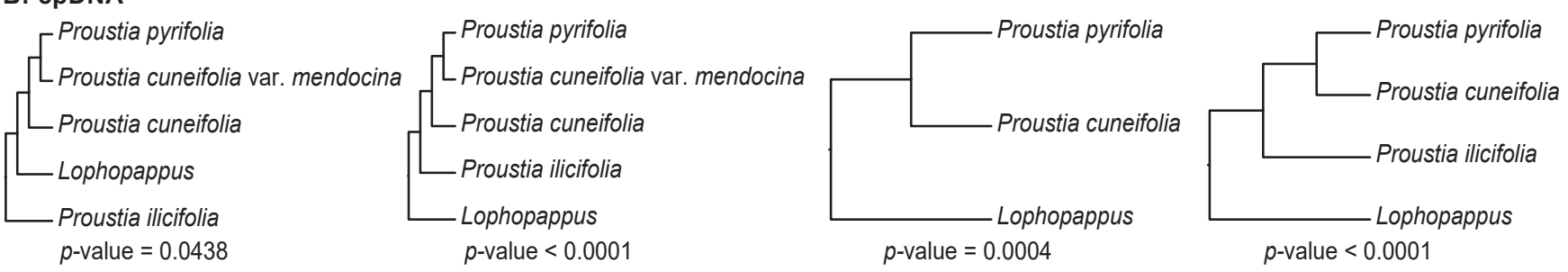

Fig. 4. Results obtained from the topology tests. Shown are simplified alternative topologies tested against nrDNA data (A) and plastid DNA data (B), with the respective $p$-values of the AU-test below. 
of corollas are found in Proustia, Lophopappus and Acourtia. Deeply 5-lobed disk corollas (instead of bilabiate ones) are present in Acourtia collina (S.Watson) Crisci or in some specimens of Lophopappus peruvianus, L. tarapacanus (Phil.) Cabrera (Fig. 1W), Proustia pyrifolia and P. cuneifolia (Fig. 1E) (Fabris, 1968; Crisci, 1974; Katinas \& al., 2013; Sancho \& al., 2014). In Proustia and Lophopappus, these unusual corollas are not always symmetrically 5 -lobed, with all the lobes similar in length, but irregularly 5-lobed, showing different stages and forming a continuum between bilabiate and 5-lobed corollas (Crisci, 1974; Katinas \& al., 2013; Sancho \& al. 2014) (Fig. $1 \mathrm{~J}, \mathrm{~W})$.

Deeply 5-lobed corollas may also appear in the other tribes of Mutisioideae, for example in Adenocaulon and Eriachaenium Sch.Bip. of Mutisieae (Funk \& al., 2016) and in Plazia, Gypothamnium and Aphyllocladus Wedd. of Onoserideae (Katinas \& al., 2008a). It is widely accepted that the ancestral corolla in Compositae was 5-lobed (Bremer, 1994; Stuessy \& al., 1996; Stuessy \& Urtubey, 2006). Stuessy \& Urtubey (2006) proposed that 5-lobed corollas of Barnadesioideae evolved in double split corollas (subbilabiate), from which bilabiate ones originated. If this evolutionary model is accepted, the irregularly 5-lobed corollas found in Proustia and Lophopappus would represent intermediate states between bilabiate and actinomorphic corollas.

Re-definition of Proustia. - According to our results, a re-definition of Proustia from its present concept is needed in order to render monophyletic taxa. In the treatment presented below, we have also thoroughly considered the criterion of ease of morphological recognition of the taxa and, at the same time, attempted to maximize nomenclatural stability (Backlund \& Bremer, 1998; Vences \& al., 2013).

The Caribbean Berylsimpsonia is confirmed as distantly related to Proustia within the Nassauvieae. The infrapetiolar spines of Berylsimpsonia vanillosma are not homologous with those of Proustia pyrifolia (Table 1; Fig. 2D). This is an important outcome since spiny structures (Fig. 2B, D) were interpreted as diagnostic features of Proustia (Fabris, 1968). Our phylogenetic analyses confirm the results of Sancho \& al. (2014), who regarded the spiny structures of Proustia as having multiple origins. These authors also suggested different ecological roles for these structures in Proustia. Berylsimpsonia has been recognized at generic level in all major recent taxonomic treatments (e.g., Hind, 2007; Katinas \& al., 2008a), a criterion maintained here. Our results indicate that Proustia ilicifolia does not form a monophyletic group with the other two species of the genus and is distantly related to them. This also agrees with the morphological analysis of Sancho \& al. (2014), who pointed out that spiny structure type, habit and type of capitulescences (Table 1; Fig. 1G, L, P) support differentiation of each species of Proustia. We therefore propose the segregation of $P$. ilicifolia to a new genus (see below). The remaining species of Proustia, P. cuneifolia and P. pyrifolia (hereafter Proustia s.str.) were recovered in a well-supported clade together with Lophopappus, with P. pyrifolia sister to Lophopappus in the analysis with nuclear data, but nested in $P$. cuneifolia in the analysis with plastid data.
Once $P$. ilicifolia is segregated to a new genus, several possibilities can be envisioned in order to taxonomically account for the other phylogenetic results: (1) to lump Lophopappus in Proustia s.str. as was proposed by Ferreyra (1995), an option agreeing with both nuclear and plastid data; (2) to segregate Proustia to its type P. pyrifolia, include Lophopappus in Proustia, and create a new genus for $P$. cuneifolia, which is in agreement with our nuclear data, but not with the plastid data; (3) to consider three independent genera: Lophopappus, the monospecific Proustia (with solely P. pyrifolia), and a new genus for P. cuneifolia; (4) to consider Lophopappus as an independent genus, sister to a reduced Proustia (Proustia s.str.) which would include P. pyrifolia and $P$. cuneifolia, as supported only by our plastid data.

From a morphological point of view, P. cuneifolia, P. pyrifolia and Lophopappus share important features, such as similar styles (atypical within Nassauvieae) and transitional corollas between actinomorphic to bilabiate (Fig. 1), which, as previously pointed out, have evolved more than once in the tribe. With respect to pollen features, which have been regarded as important in defining genera within Nassauvieae (Crisci, 1974), it is not possible to establish a sharp differentiation among these taxa. Indeed, $P$. cuneifolia and $P$. pyrifolia have Trixis exine type whereas some species of Lophopappus have Proustia exine type and some others Trixis exine type.

The solitary or few capitula (2-4) of Lophopappus (Fig. $1 Y)$, however, contrast with the capitulescences of numerous capitula in P. cuneifolia and P. pyrifolia (Figs. 1G, P, 2A, C). Some differences concerning leaf venation can also be stressed (Hickey, 1979). The species of Lophopappus have a typical acrodromous (i.e., with two or more primary or strongly developed secondary veins toward the leaf apex; Fig. 1U) or actinodromous venation (i.e., three or more primary veins diverging radially from a single point; Katinas \& al., 2013) whereas in $P$. pyrifolia and $P$. cuneifolia dominates pinnate venation (i.e., with a single primary vein serving as the origin for the higher order venation; Fig. $1 \mathrm{~A}-\mathrm{C}, \mathrm{H}, \mathrm{M}$ ).

In summary, morphological data are consistent with the segregation of Proustia and Lophopappus as separate genera, but not with the segregation of $P$. cuneifolia as a new generic entity. The only study known to us in which Lophopappus and Proustia have been reunited is the treatment of Ferreyra (1995) for the "Flora of Peru". This option has the advantage of being consistent with the phylogenetic trees obtained from both nuclear and plastid data. Conversely, these genera have been considered as separate units in all recent taxonomic treatments (Fabris, 1968; Cabrera, 1977; Hind, 2007; Katinas \& al., 2008a, 2013), floristic checklists (e.g., Zuloaga \& al., 2008; Moreira \& al., 2012) and phylogenetic studies (e.g., Katinas \& al., 2008b; Panero \& Funk, 2008; Luebert \& al., 2009; Simpson $\&$ al., 2009; Panero \& al., 2014), but is only consistent with our phylogenetic results derived from plastid data. However, our topology test failed to reject Lophopappus and Proustia as reciprocally monophyletic with the nuclear data (Fig. 4). Given the topological uncertainty of the phylogenetic analyses in this region of the tree, we take a morphologically consistent and nomenclaturally conservative approach and do not modify 
the circumscription of Lophopappus and Proustia (other than segregating $P$. ilicifolia) thus following the recent taxonomic literature.

In agreement with our arguments presented above, we recognize two species in Proustia, namely P. cuneifolia and P. pyrifolia (the type). Proustia cuneifolia f. mendocina varied its placement in the phylogenetic trees (it was recovered sister to P. pyrifolia in the plastid tree and nested within P. cuneifolia in the nuclear tree). From all the subordinate taxa of $P$. cuneifolia the form mendocina is the most distinctive by its spinosedentate leaf blades (Fig. 1B). However, P. cuneifolia f. mendocina shares important morphological features with the other subordinate taxa of $P$. cuneifolia, especially those concerning to the thorny capitulescense, a very distinguishing feature of this species. Furthermore, P. cuneifolia f. mendocina has a marginal geographical distribution within $P$. cuneifolia (Fig. 5). In the light of this evidence, we propose to maintain P. cuneifolia. f. mendocina as a subordinate taxon of $P$. cuneifolia, although

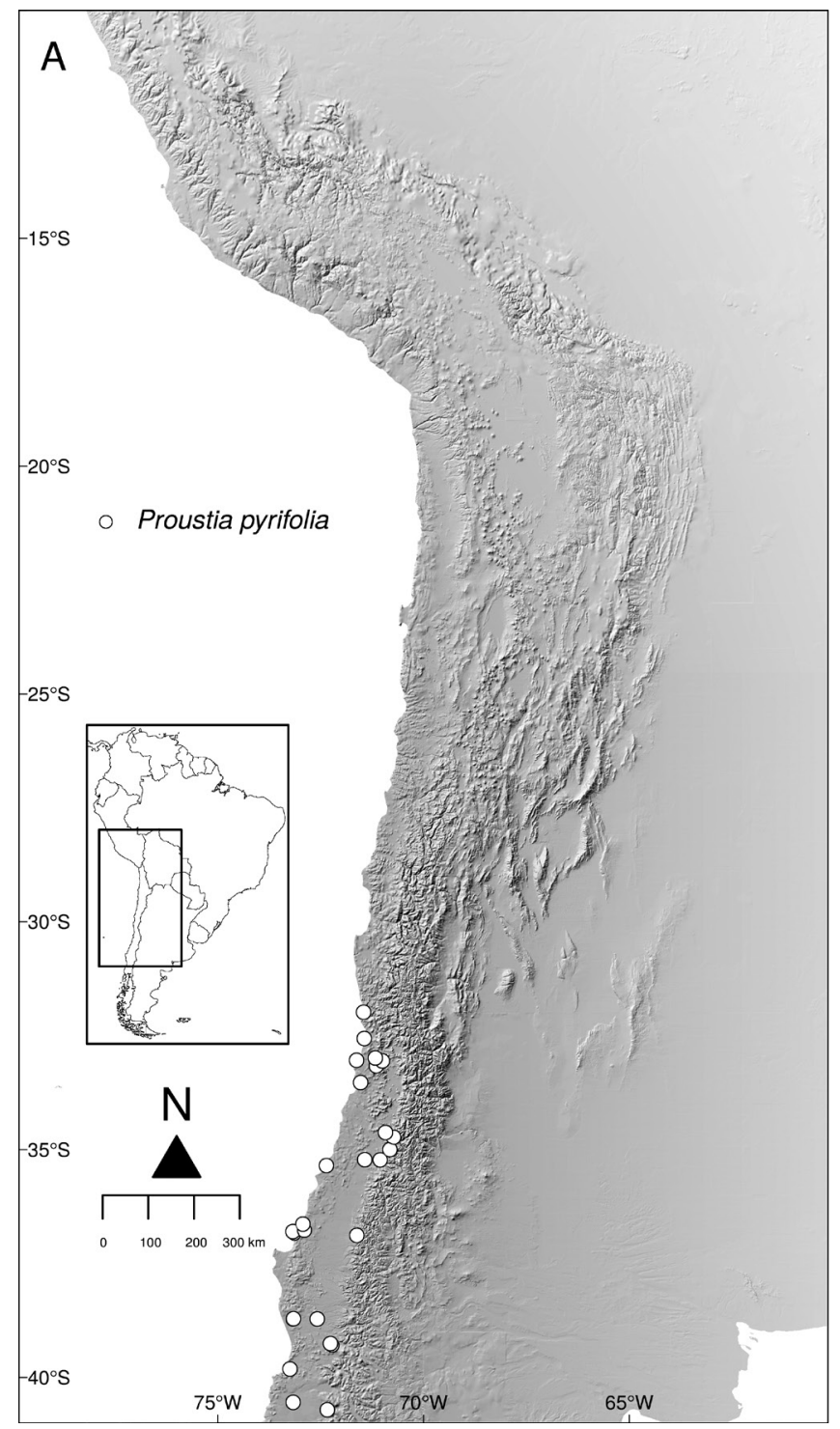

assigning it a new rank of subspecies. For the same reasons, we also propose to raise $P$. cuneifolia $\mathrm{f}$. cinerea, $P$. cuneifolia var. mollis and P. cuneifolia f. tipia, to the rank of subspecies. All these taxa are geographical and morphological variants within $P$. cuneifolia. With respect to the other genera once related to Proustia, the taxonomy of Lophopappus has been fully revised by Katinas \& al. (2012) and a treatment of Berylsimpsonia has been provided by Turner (1993).

\section{TAXONOMIC TREATMENT}

I. Proustia Lag., Amen. Nat. Españ. 1: 33. 1811 - Type: P. pyrifolia DC.

A South American genus comprising two species, P. cuneifolia and P. pyrifolia. Distinguishing characters of these species are provided in Table 1. The morphology of Proustia was thoroughly described by Fabris (1968) and Sancho \& al. (2014).

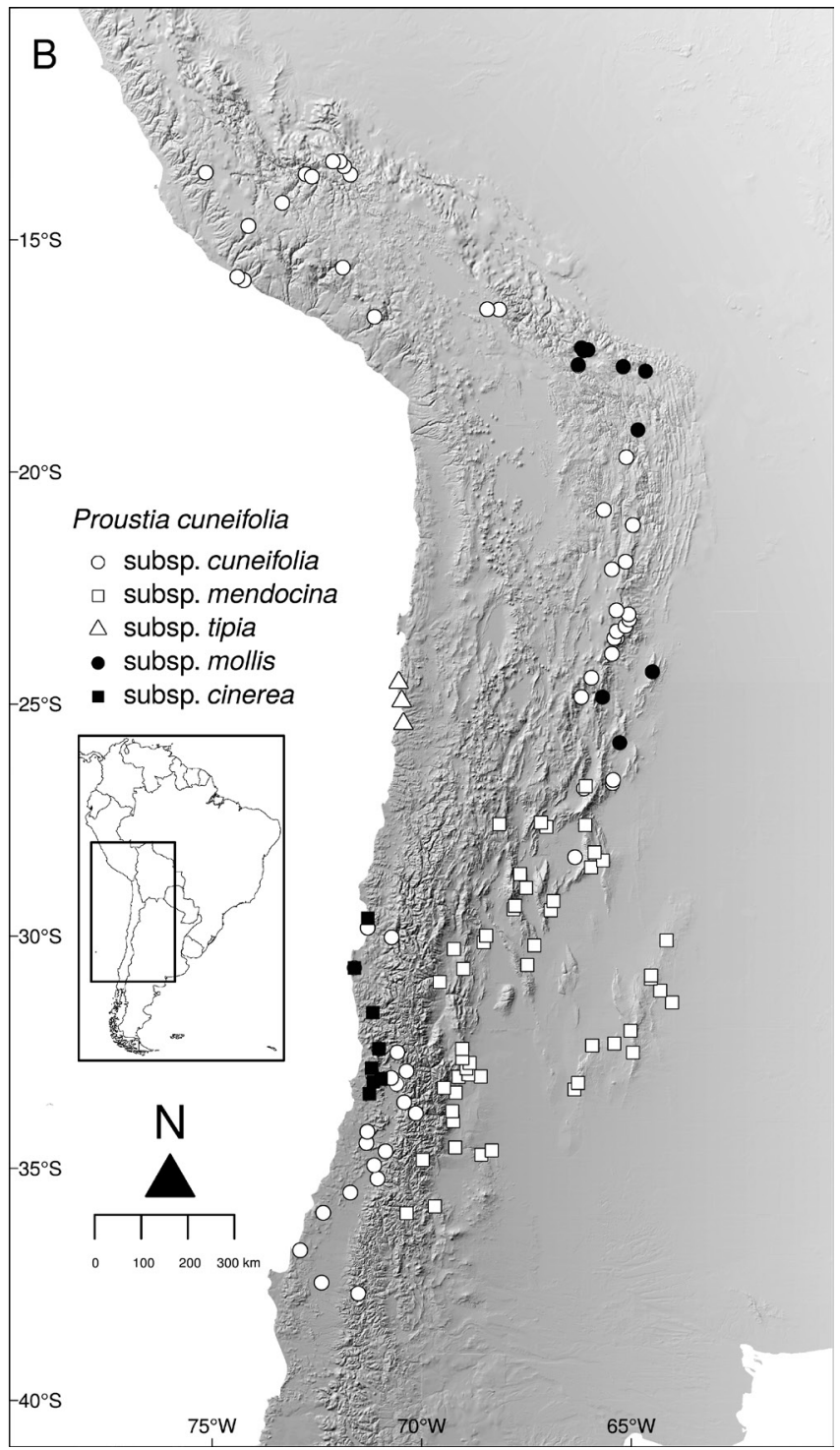

Fig. 5. Distribution map of Proustia. A, P. pyrifolia; B, P. cuneifolia. 
We follow Fabris (1968) regarding the synonymy of most species. Therefore, we only provide the basionyms of each taxon and the synonymy changes proposed herein. In order to hold a nomenclaturally conservative approach, we maintain two of the sections included by Fabris (1968) for the treatment of Proustia: sect. Proustia (including the type, P. pyrifolia) and sect. Harmodia D.Don (including P. cuneifolia) (Table 1).

\section{Ia. Proustia sect. Proustia}

1. Proustia pyrifolia DC. in Ann. Mus. Natl. Hist. Nat. 19: 70, pl. 4. 1812 - Holotype: CHILE. "Prope Talcahuano", without collector, s.n. (herb. Lagasca y Segura) (G-DC barcode G00318288, photo!).

= Proustia pyrifolia f. glandulosa (DC.) Fabris in Revista Mus. La Plata, Secc. Bot. 11: 30. $1968 \equiv$ P. glandulosa DC., Prodr. 7: 27. 1838 - Holotype: CHILE. "Valparaiso", Gaudichaud 145 (G-DC barcode G00318276, photo!; isotypes: G-DC barcode G00358907, photo!, P barcode P03733626, photo!; possible isotype: Gaudichaud 147, P barcode P00724943, photo!).

Distribution. - Proustia pyrifolia is endemic to Chile (Fig. $5 \mathrm{~A})$. This species of vines inhabits sclerophyllous Mediterranean and lauriphyllous temperate forests.

Ib. Proustia sect. Harmodia D.Don in Trans. Linn. Soc. London 16: 202. 1830 - Type: Proustia cuneifolia D.Don

1. Proustia cuneifolia D.Don in Trans. Linn. Soc. London 16: 202. 1830 - Holotype: CHILE. Coquimbo, Caldcleugh s.n., ex herb. Lambert (G?, fide Miller, 1970).

Distribution. - Proustia cuneifolia ranges from Peru to Central Chile and Argentina (Fig. 5B). This species of shrubs with thorny capitulescences inhabits sclerophyllous forests, thickets and desert scrub.

\section{Key to subspecies of Proustia cuneifolia}

1. Leaf blade margins entire, denticulate or spinose-dentate

Leaf blade margins strongly spinose .. subsp. mendocina

2. Leaf blade oblong, elliptic, narrowly elliptic or narrowly

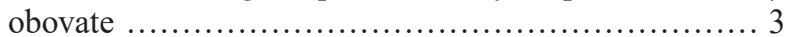

2. Leaf blade widely elliptic to orbiculate ...... subsp. tipia

3. Leaves glabrous or puberulent abaxially ... subsp. cuneifolia

3. Leaves tomentose abaxially ....................... 4

4. Leaves papery; central Chile ............. subsp. cinerea

4. Leaves coriaceous; Bolivia and NW Argentina subsp. mollis

1a. Proustia cuneifolia subsp. cinerea (Phil.) Luebert, stat. nov. $\equiv P$. cinerea Phil. in Linnea 29: $109.1858 \equiv P$. cuneifolia f. cinerea (Phil.) Fabris in Revista Mus. La Plata, Secc. Bot. 11: 48. 1968 - Lectotype (designated here): CHILE. "In colli S. Cristóval, urbi Santiago proximo", Philippi s.n. (SGO No. 44594, photo!; isotypes: B destroyed, F photo neg. 15903!, HAL barcode HAL0113112, photo!, NY barcode 00232662, photo!, P barcode P00732724, photo!, S No. S-R-5277!, SGO No. 60865, photo!; possible isotype: $\mathrm{K}$ barcode K000504353, photo!).

\section{1b. Proustia cuneifolia D.Don subsp. cuneifolia}

$=$ Proustia pungens var. oblongifolia Wedd., Chlor. Andina 1: 23. $1855 \equiv$ P. cuneifolia f. oblongifolia (Wedd.) Fabris in Revista Mus. La Plata, Secc. Bot. 11: 43. 1968 - Lectotype (designated here): BOLIVIA: "1839", Pentland 29 (P barcode P03733601, photo!; isolectotype: $\mathrm{P}$ barcode P03733604, photo!).

Nomenclatural notes. - The isolectotype of Proustia pungens $\beta$ oblongifolia Wedd. at $\mathrm{P}$, barcode $\mathrm{P} 03733604$, includes the following information: "Valleés à l'E de la Paz. alt. 12 à 8000 pds angl." In the original publication it is not clearly stated which specimens are assigned to the variety oblongifolia. In addition, none of the specimens at $\mathrm{P}$ were annotated by Weddell. Then, the lectotype was chosen among those specimens cited in the protologue on the basis of Weddell's description.

1c. Proustia cuneifolia subsp. mendocina (Phil.) Katinas, stat. nov. $\equiv P$. mendocina Phil. in Anales Univ. Chile 36: 176. $1870 \equiv P$. cuneifolia f. mendocina (Phil.) Fabris in Revista Mus. La Plata, Secc. Bot. 11: 44. $1968 \equiv$ P. cuneifolia var. mendocina (Phil.) Ariza in Darwiniana 33: 371. 1995 - Lectotype (designated here): ARGENTINA. Mendoza, Philippi s.n. (SGO No. 60866, photo!; isotypes: CORD barcode CORD00004731, photo!, GOET barcode GOET001921, photo!, SGO No. 60867, photo!).

1d. Proustia cuneifolia subsp. mollis (Kuntze) G.Sancho, stat. nov. $\equiv P$. angustifolia var. mollis Kuntze, Revis. Gen. Pl. 3(3): 168. $1898 \equiv$ P. cuneifolia var. mollis (Kuntze) Cabrera, Fl. Jujuy 10: 615. 1978 - Holotype: BOLIVIA. "Bei Cochabamba, 26 Mar 1892, 3000 m", Kuntze s.n. (NY barcode 00232661 , photo!; isotype: US barcode 00119620 , photo!).

= Proustia cuneifolia f. angustifolia (Wedd.) Fabris in Revista Mus. La Plata, Secc. Bot. 11: 48. $1968 \equiv$ P. angustifolia Wedd., Chlor. Andina 1: 24. 1855 - Holotype: BOLIVIA. Chuquisaca, "sommet de la côte de Cachimayo", d'Orbigny 1271 (P barcode P00732723, photo!).

Remarks. - The morphology of the type of $P$. angustifolia var. mollis clearly coincides with that of the type of $P$. angustifolia. However, the concept of Proustia angustifolia var. mollis sensu Cabrera (1978) disagrees with Kuntze's in that the specimens from Jujuy and Salta are unarmed (vs. capitulescence strongly thorny in Kuntze's type specimen). The specimens of $P$. cuneifolia var. mollis included in our analyses are unarmed and were collected in Salta and Jujuy. We preliminary consider them as P. cuneifolia var. mollis until the status of these individuals is clarified.

1e. Proustia cuneifolia subsp. tipia (Phil.) Luebert, stat. nov. $\equiv$ P. tipia Phil., Fl. Atacam.: 28. $1860 \equiv$ P. cuneifolia f. tipia (Phil.) Fabris in Revista Mus. La Plata, Secc. Bot. 11: 47. 
1968 - Holotype: CHILE. Atacama, "ad Hueso Parado et Paposo", Philippi s.n. (SGO No. 60869!).

II. Spinoliva G.Sancho, Luebert \& Katinas, gen. nov. - Type: S. ilicifolia (Hook. \& Arn.) G.Sancho (三Proustia ilicifolia Hook. \& Arn.).

Description. - Shrubs or small trees, young branches unarmed, subglabrous, glandular with minute glands, older branches glabrous. Leaves alternate, sessile, blades obovate to elliptic, coriaceous, margin spiny, glabrous or tomentose below. Capitula in thyrses, those of secondary axes in spiciform arrangements; capitula sessile, homogamous, discoid. Involucre cylindrical, phyllaries 4-seriate, imbricate, coriaceous. Receptacle epaleate, flat or convex, fimbrillate to setiferous. Florets (2)3-5, isomorphic, bisexual, corolla white to pinkish, bilabiate, outer lip distinctly 3-lobed, inner lip deeply regularly or irregularly divided. Anthers caudate, apical appendages acute. Style bilobed, lobes apically rounded, externally hairy on distal half, hair apices more or less rounded, internally completely covered by stigmatic papillae, base swollen, surrounded by a nectariferous ring. Cypselae nearly prismatic, subglabrous near base, sericeous with twin hairs distally, 4-ribbed. Pappus of 2 series of white, semi-caducous bristles, flat and scabrid at base, apex somewhat barbellate-plumose, bristles of outer series slightly shorter and thinner.

Etymology. - The name refers to the Latin word spina because of the spiny leaf margins and the local name "olivillo", given to this plant by its leaves similar to those of olive tree (Olea europea L.).

Distribution. - Spinoliva is endemic to Central Chile.

Species. - Spinoliva is a monospecific genus with the single species $S$. ilicifolia and two subspecies.

1. Spinoliva ilicifolia (Hook. \& Arn.) G.Sancho, comb. nov. $\equiv$ Proustia ilicifolia Hook \& Arn., Bot. Beechey Voy.: 28. 1830 ("1841") $\equiv$ P. pungens var. ilicifolia (Hook. \& Arn.) DC., Prodr. 7: 28. 1838 - Neotype (designated here): CHILE. Coquimbo, Prov. Elqui, "road from Huanta to
Fig. 6. Spinoliva ilicifolia. A, General aspect; B, Capitulum; C, Outter phyllary; D, Middle phyllary; E, Inner phyllary; F, Bilabiate corolla, ventral view; G, Bilabiate corolla, lateral view; H, Sub-bilabiate corolla showing asymmetrical lobes; I, Stamen; J, Style; K, Cypsela with pappus. — Scales: A = $1 \mathrm{~cm}$; B-H \& K = $1 \mathrm{~mm} ; \mathrm{I}=0.5 \mathrm{~mm} ; \mathrm{J}=0.25 \mathrm{~mm}$. Drawn from Chile, Coquimbo, Paihuano, 5 Feb 1883, without collector s.n. (LP). Drawn by Samanta Faiad.

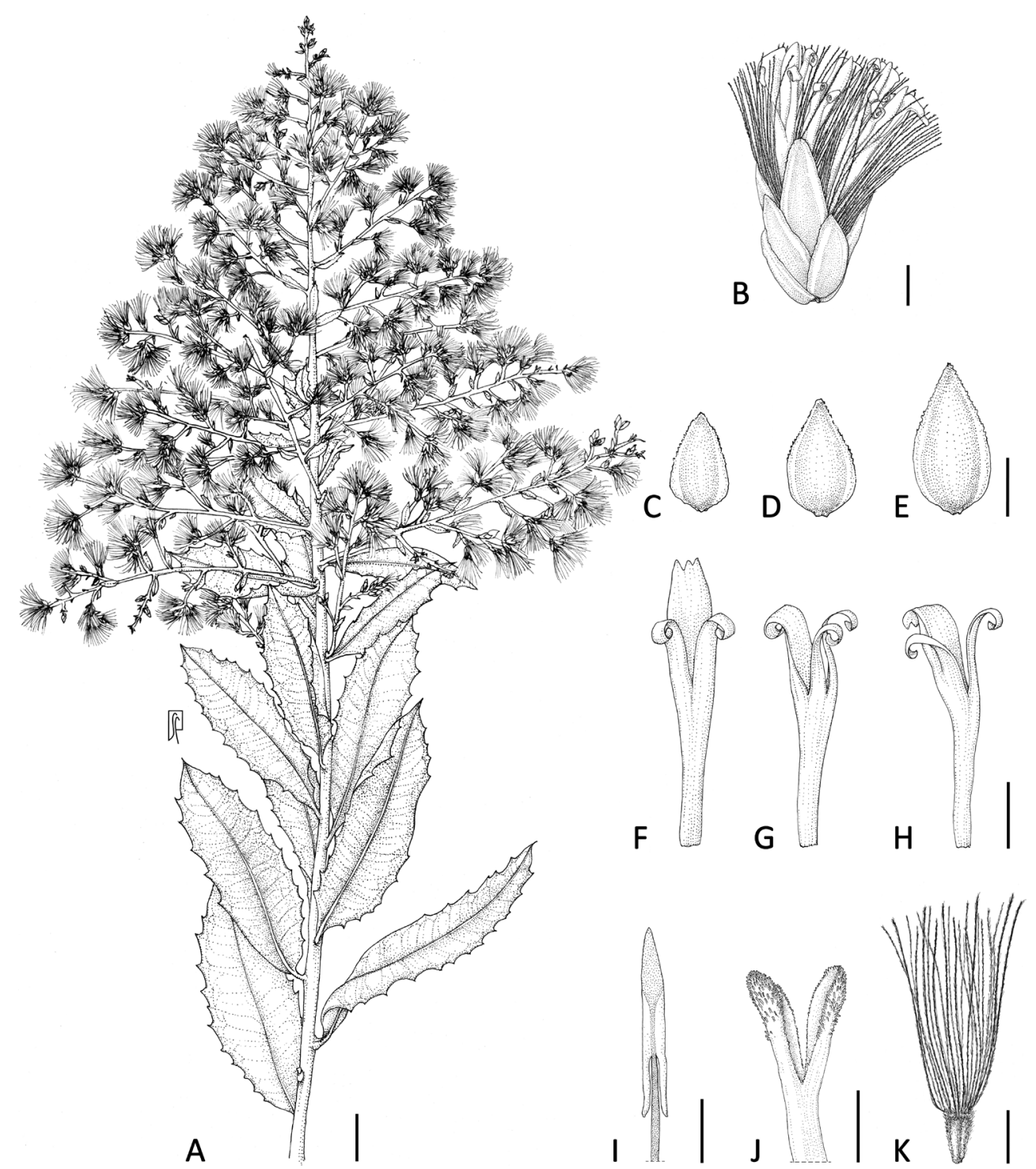


Juntas del Toro, $29.96540^{\circ} \mathrm{S}, 70.13243^{\circ} \mathrm{W}, 1950 \mathrm{~m}, 1$ April 2017', Luebert \& Böhnert 3717 (SGO No. 168351!; isoneotypes: B barcode B 100680765!, BONN!, CONC No. 184772!, E barcode E00822517!, EIF No. 12270!, LP barcode LP000172!).

$=$ Proustia reticulata Phil. in Anales Univ. Chile 18: 50. 1861, nom. illeg., non Don $1830 \equiv$ Acourtia reticulata (Lag. ex D.Don) Reveal \& R.M.King in Phytologia 27(4): 231. 1973 E Proustia olivillo Phil. in Anales Univ. Chile 85: 838. 1894 (replacement name for $P$. reticulata Phil.) - Holotype: CHILE. Atacama, "Agua de Antibianco en 2.400 metros de elevación", Volckmann s.n. (SGO n.v.).

Description. - Shrubs or small trees, up to $4 \mathrm{~m}$ tall, young branches unarmed, somewhat striate, subglabrous, glandular with minute glands, older branches glabrous. Leaves alternate, sessile, blades 4-7.5 × 1-2.8 cm, obovate to elliptic, coriaceous, venation camptodromous, glandular, glabrous or tightly, white tomentose beneath, margins spiny. Capitula in thyrses, those of secondary axes in spiciform arrangements; capitula sessile, homogamous, discoid. Involucre 2.5-4 $\mathrm{mm}$ high, cylindrical, phyllaries 4-seriate, imbricate, inner progressively longer, outermost $0.8-1.8 \times 0.7-1 \mathrm{~mm}$, innermost $2.8-3.4 \times 1.1-1.8 \mathrm{~mm}$, coriaceous, commonly centrally shiny and thicker, margins scarious, glandular. Receptacle epaleate, flat or convex, fimbrillate to setiferous. Florets (2)3-5, isomorphic, bisexual, corolla 4.6-5.5 mm long, bilabiate, outer lip ca. $2.5 \mathrm{~mm}$ long, hairy with unicellular acute trichomes, distinctly 3 -lobed, lobes ca. $1 \mathrm{~mm}$ long, regularly or rarely irregularly incised, inner lip deeply divided, lobes 2.5-3 mm long, coiled. Anthers 2.3-2.5 mm long, caudate, tails $0.5-0.8 \mathrm{~mm}$ long, glabrous or with a few projections, apical appendages acute. Style bilobed, branches ca. $0.5 \mathrm{~mm}$ long, apex rounded, externally hairy on distal half, internally completely covered by stigmatic papillae, base swollen surrounded by a nectariferous ring with many stomata. Cypselae ca. $1.4 \mathrm{~mm}$ long, nearly prismatic, subglabrous near base, sericeous distally with twin hairs, 4-ribbed, short carpopodium at base. Pappus of 2 series of white, semi-caducous bristles, 3.7-4.2 mm long, flat and scabrid at base, apex somewhat barbellate-plumose, bristles of outer series slightly shorter and thinner. Figs. 1H-L, 2E, F, 6, 7A.

Pollen. - The pollen grains are radially symmetrical and isopolar; subprolate in equatorial view, circular in polar view. The polar diameter is $28-33 \mu \mathrm{m}$ and the equatorial diameter 19-29 $\mu \mathrm{m}$. The grains are tricolporate, and the colpi long with a microgranulate membrane. The endoaperture is lalongate. As a general description, the exine is tectate, microechinate and $2-4.5 \mu \mathrm{m}$ thick. Two types of exine structure are found: Trixis type (ectosexine thinner than endosexine, both sublayers columellate) or Proustia type (ectosexine of same thickness as endosexine, both sublayers columellate). The sexine is about 2 or 3 times as thick as nexine. The internal tectum is parallel to the nexine. The nexine is thickened towards the apertures forming costae (Tellería \& al., 2003).

Leaf anatomy. - The blades of Spinoliva ilicifolia are covered by scattered glands (vesicular filiform trichome; Ramayya, 1962) and oblique-septate-flagellate trichomes. The blades are amphistomatic. In cross section, the blades show a thick cuticle and a single-layered epidermis of polygonal cells, with straight tangential walls. The mesophyll is dorsiventral with one palisade layer and spongy tissue. Two or more, commonly three, vascular bundles are found at the midrib level. The vascular bundles are completely encircled by sclerenchyma. Below the vascular bundles, inflated cells with refractive content are arranged as if they have secretory products.
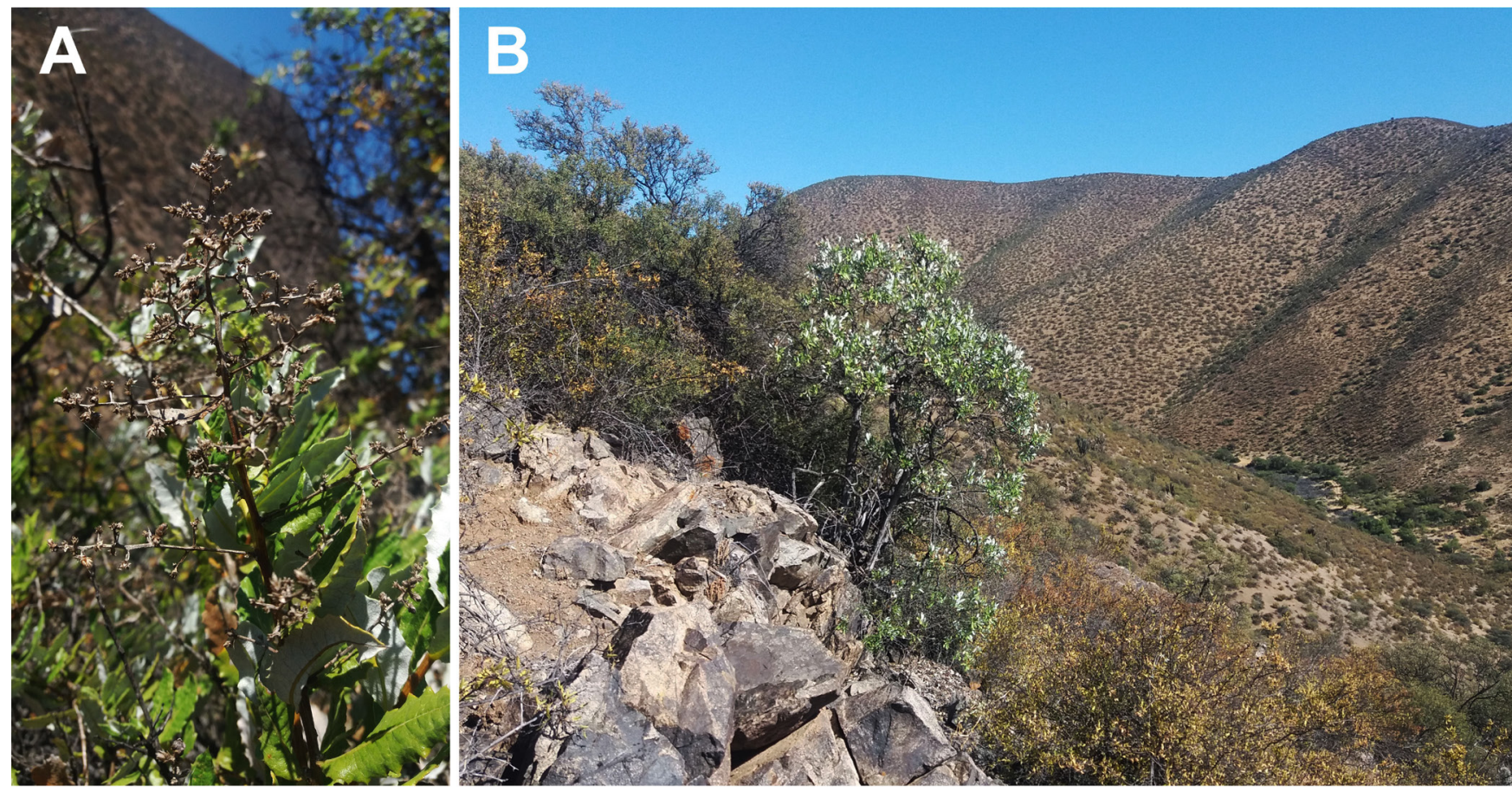

Fig. 7. Spinoliva ilicifolia. A, Detail of branch; B, Specimen in native hábitat. - Photos: G. Sancho. 
Distribution and habitat. - Spinoliva ilicifolia is endemic to Chile between the Regions of Atacama and Santiago (Fig. 8). This species inhabits desert, thorny and sclerophyllous Mediterranean scrubs dominated by species such as Adesmia argentea Meyen and Bulnesia chilensis Gay between 300 to $1800 \mathrm{~m}$ or Flourensia thurifera (Molina) DC. and Colliguaja odorifera Molina between 300 and $2300 \mathrm{~m}$ (Luebert \& Pliscoff, 2006) (Fig. 7B).

Nomenclatural notes. - Hooker \& Arnott (1830: 28) described Proustia ilicifolia based on a specimen from Coquimbo, Chile. This specimen was collected during the expedition commanded by Captain Beechey, probably in May 1828 ("Hab. Coquimbo"). We failed to find original material at $\mathrm{E}$ and $\mathrm{K}$. Indeed, Noltie (2010) indicated that no original material can be assigned to this species in E or K. Fabris (1968), on the other hand, did not cite type material for this species. A neotype is selected above to preserve the usage established by previous applications of the name in agreement to the Art. 9.16

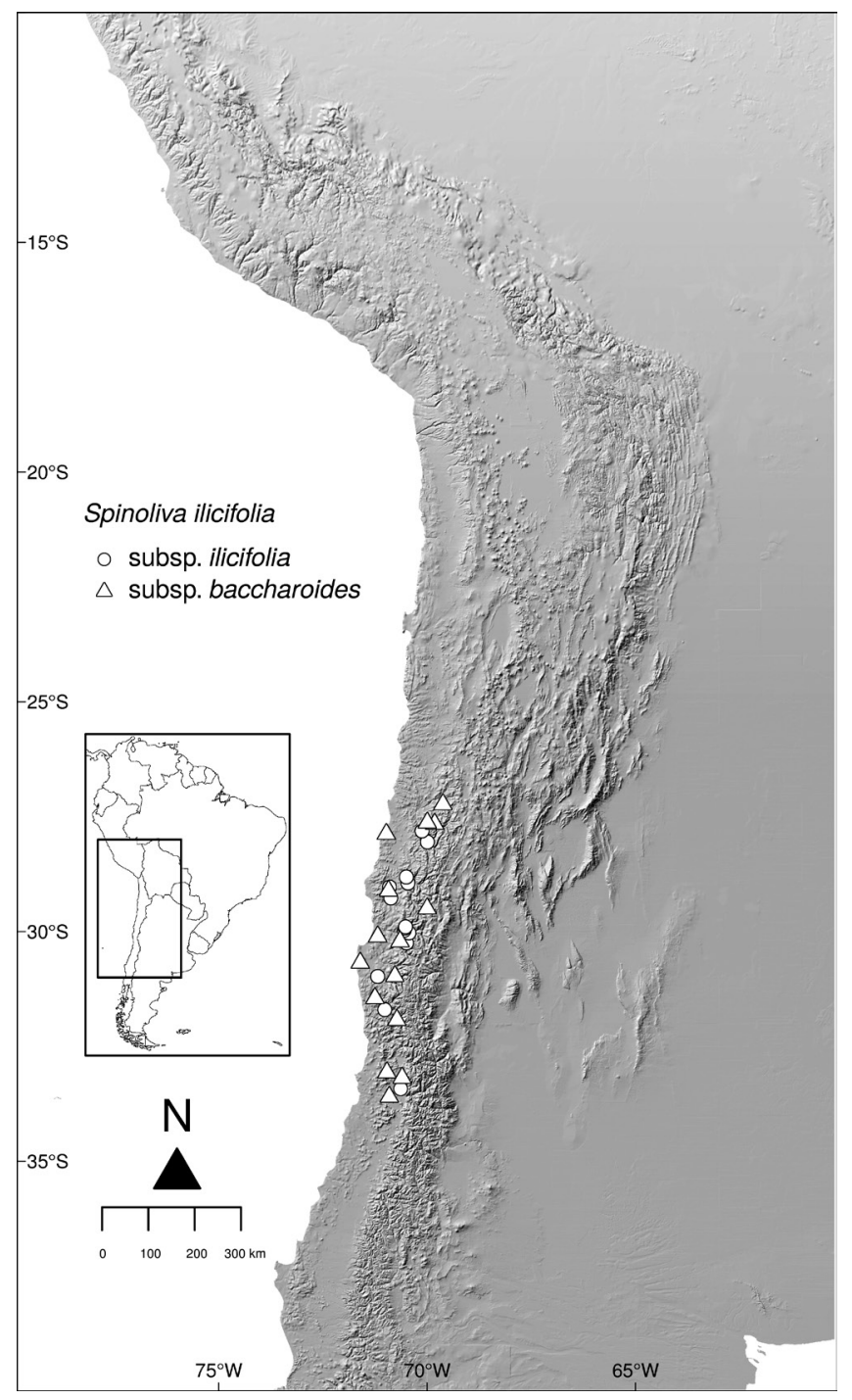

Fig. 8. Distribution map of Spinoliva ilicifolia.
(McNeill \& al., 2012). The specimen selected here was collected in Coquimbo, the same area where the specimen designated by Hooker and Arnott was originally gathered.

\section{Key to subspecies of Spinoliva ilicifolia}

1. Leaf blades glabrous on both surfaces .... subsp. ilicifolia

1. Leaf blades tightly, white-tomentose beneath .......... subsp. baccharoides

\section{1a. Spinoliva ilicifolia subsp. ilicifolia}

1b. Spinoliva ilicifolia subsp. baccharoides (D.Don ex Hook. \& Arn.) G.Sancho, comb. \& stat. nov. $\equiv$ Proustia baccharoides D.Don ex Hook. \& Arn. in Compan. Bot. Mag. 1: 106. $1835 \equiv$ P. ilicifolia $\mathrm{f}$. baccharoides (D.Don. ex Hook. \& Arn.) Fabris in Revista Mus. La Plata, Secc. Bot. 11: 37. 1968 - Holotype: CHILE. "Coquimbo", without collector, s.n. (K barcode K001092242!).

Nomenclatural notes. - Fabris (1968: 37, 38) designated the specimen collected in Coquimbo by Macrae in 1825 (at K) as the lectotype of Proustia baccharoides: K (K000504352 ex Herb. Benthamianum!). However, there is another specimen at K (K001092242 ex Herb. Hookerianum) annotated by Hooker indicating: "Coquimbo, Proustia". This specimen was labeled by D.J.N. Hind as "Holotype" of P. baccharoides. With this evidence, we consider this last specimen the holotype of $P$. baccharoides. In this new frame, Fabris's lectotype should be superseded as indicated by Art. 9.19 (McNeill \& al., 2012).

\section{AUTHOR CONTRIBUTIONS}

GS, LK and FL designed the study; all authors contributed materials; GS, JNVB and FL conducted analyses; GS, LK and FL prepared the taxonomic treatment; GS and FL led the writing. All authors approved the final version of the manuscript. — FL, https://orcid.org/0000-00032251-4056; GS, sancho@fcnym.unlp.edu.ar

\section{ACKNOWLEDGEMENTS}

This work was funded by Agencia Nacional de Promoción Científica y Tecnológica (Secretaría de Ciencia y Técnica [PICT 2012-01683]), Comisión Nacional de Investigaciones Científicas y Técnicas, CONICET (PIP 2013/2015 \# 0446) and Universidad Nacional de La Plata (I+D N/687 and N/814), Argentina to GS, LK, JVB. Funding was provided to FL by the Dahlem Centre of Plant Sciences (DCPS) of the Freie Universität Berlin and the Nees-Institut für Biodiversität der Pflanzen (Universität Bonn). Field work was supported by Fondecyt grant 1150425 to AMM and DFG-SFB 1211 to FL. Tim Böhnert, Michael Dillon, Hartmut Hilger and Mélica Muñoz-Schick participated in field campaigns. Juliana Chacón, Patricio Medina, Sebastián Teillier and Maximilian Weigend kindly provided material. Jimena Arriagada (SGO) provided images of type specimens. We acknowledge the curators of B, F, GH, S, SGO and US for the loan of specimens and for allowing us to remove material from their collections for DNA extraction (B, S, SGO, US). We thank Nicole Schmandt and Simona Kostova 
for valuable help in the lab; Nicholas Hind and Vanezza Morales for valuable information on type specimens at K. Special thanks go to Fabiola Areces (UPRRP), Susy Fuentes (B) and Pedro González (CISAT-CITMA, Cuba) for their help with material of Berylsimpsonia. We are also grateful to Samanta Faiad for the illustration of Spinoliva ilicifolia. We are grateful to the valuable comments of two anonymous reviewers. This research received support from the SYNTHESYS project http://www.synthesys.info/ which is financed by the FP6 "Structuring the European Research Area" (grant GB-TAF-4514) and European Community Research Infrastructure Action under the FP7 “Capacities” (grants FR-TAF-1977, SE-TAF-4797) Programmes.

\section{LITERATURE CITED}

Baird, K.E., Funk, V.A., Wen, J. \& Weeks, A. 2010. Molecular phylogenetic analysis of Leibnitzia Cass. (Asteraceae: Mutisieae: Gerberacomplex), an Asian-North American disjunct genus. J. Syst. Evol. 48: 161-174. https://doi.org/10.1111/j.1759-6831.2010.00077.x

Baldwin, B.G. \& Markos, S. 1998. Phylogenetic utility of the external transcribed spacer (ETS) of 18S-26S rDNA: Congruence of ETS and ITS trees of Calycadenia (Compositae). Molec. Phylogen. Evol. 10: 449-463. https://doi.org/10.1006/mpev.1998.0545

Bayer, R.J., Greber, D.G. \& Bagnall, N.H. 2002. Phylogeny of Australian Gnaphalieae (Asteraceae) based on chloroplast and nuclear sequences, the $\operatorname{trn} L$ intron, $\operatorname{trn} L / t r n F$ intergenic spacer, matk, and ETS. Syst. Bot. 27: 801-814. https://doi.org/10.1043/0363-6445-27.4.801

Backlund, A. \& Bremer, K. 1998. To be or not to be: Principles of classification and monotypic plant families. Taxon 47: 391-400. https://doi.org/10.2307/1223768

Bremer, K. 1994. Asteraceae: Cladistics and classification. Portland: Timber Press.

Cabrera, A.L. 1953. Compuestas peruanas nuevas o críticas. Bol. Soc. Argent. Bot. 5: 37-50.

Cabrera, A.L. 1971. Fitogeografía de la República Argentina. Bol. Soc. Argent. Bot. 14: 1-42.

Cabrera, A.L. 1977. Mutisieae - Systematic review. Pp. 1039-1066 in: Heywood, V.H., Harborne, J.B. \& Turner, B.L. (eds.), The biology and chemistry of the Compositae, vol 1. London: Academic Press.

Cabrera, A.L. 1978. Proustia. Pp. 611-615 in: Cabrera, A.L. (ed.), Flora de la provincia de Jujuy, vol. 10. Buenos Aires: Colección Científica del INTA.

Candolle, A.P. de 1838. Prodromus systematis naturalis regni vegetabilis, pars 7. Parisiis [Paris]: Treuttel et Würtz. https://doi.org/10.5962/bhl.title.286

Chacón, J., Luebert, F. \& Weigend, M. 2017. Biogeographic events are not correlated with diaspore dispersal modes in Boraginaceae. Frontiers Ecol. Evol. 5: 26. https://doi.org/10.3389/fevo.2017.00026

Crisci, J.V. 1974. A numerical-taxonomic study of the subtribe Nassauviinae (Compositae, Mutisieae). J. Arnold Arbor. 55: 568-610.

Crisci, J.V. 1980. Evolution in the subtribe Nassauvieae (Compositae, Mutisieae): A phylogenetic reconstruction. Taxon 29: 213-224.

Darriba, D., Taboada, G.L., Doallo, R. \& Posada, D. 2012. jModelTest 2: More models, new heuristics and parallel computing. Nature, Meth. 9: 772. https://doi.org/10.1038/nmeth.2109

Degnan, J.H. \& Rosenberg, N.A. 2009. Gene tree discordance, phylogenetic inference and the multispecies coalescent. Trends Ecol. Evol. 24: 332-340. https://doi.org/10.1016/j.tree.2009.01.009

Don, D. 1830. Description of the new genera and species of the class Compositae belonging to the floras of Peru, Mexico, and Chile. Trans. Linn. Soc. London., Bot. 16: 169-303. https://doi.org/10.1111/j.1095-8339.1829.tb00136.x
Doyle, J.J. \& Dickson, E.E. 1987. Preservation of plant samples for DNA restriction endonuclease analysis. Taxon 36: 715-722. https://doi.org/10.2307/1221122

Erbar, C. \& Leins, P. 2015. Diversity of styles and mechanisms of secondary pollen presentation in basal Asteraceae: New insights in phylogeny and function. Flora 217: 109-130. https://doi.org/10.1016/j.flora.2015.10.002

Fabris, H.A. 1968. Revisión del género Proustia (Compositae). Revista Mus. La Plata, Secc. Bot. 11: 23-49.

Felsenstein, J. 1981. Evolutionary trees from DNA sequences: A maximum likelihood approach. J. Molec. Evol. 17: 368-376. https://doi.org/10.1007/BF01734359

Ferreyra, R. 1995. Flora of Peru: Family Asteraceae, part VI. Fieldiana Botany, n.s., 35. Chicago: Field Museum of Natural History. https://doi.org/10.5962/bhl.title.2604

Funk, V.A., Susanna, A., Stuessy, T.F. \& Bayer, R.J. (eds.) 2009. Systematics, evolution, and biogeography of Compositae. Vienna: International Association for Plant Taxonomy, Institute of Botany, University of Vienna.

Funk, V.A., Pasini, E., Bonifacino, J.M. \& Katinas, L. 2016. Home at last: the enigmatic genera Eriachaenium and Adenocaulon (Compositae, Mutisioideae, Mutisieae, Adenocaulinae). PhytoKeys 60: 1-19. https://doi.org/10.3897/phytokeys.60.6795

Hickey, L.J. 1979. A revised classification of the architecture of dycotyledoneous leaves. Pp. 25-39 in: Metcalfe, C.R. \& Chalk, L. (eds.), Anatomy of the dicotyledons, ed. 2, vol. 1. Oxford: Clarendon Press.

Hind, D.J.N. 2007. Mutisieae Cass. Pp. 90-123 in: Kadereit, J.W. \& Jeffrey, C. (eds.), The families and genera of vascular plants, vol. 8. Berlin: Springer.

Hooker, W.J. \& Arnott, G.A.W. (eds.) 1830 ("1841”). Compositae. Pp 28-33 in: The Botany of Captain Beechey's Voyage. London: Henry G. Bohn. https://doi.org/10.5962/bhl.title.246

Jara-Arancio, P., Vidal, P.M., Panero, J.L., Marticorena, A., Arancio, G. \& Arroyo, M.T.K. 2017. Phylogenetic reconstruction of the South American genus Leucheria Lag. (Asteraceae, Nassauvieae) based on nuclear and chloroplast DNA sequences. Pl. Syst. Evol. 303: 221-232. https://doi.org/10.1007/s00606-016-1366-7

Johnson, L.A. \& Soltis, D.E. 1994. matK DNA sequences and phylogenetic reconstruction in Saxifragaceae s. str. Syst. Bot. 19: 143-156. https://doi.org/10.2307/2419718

Katinas, L. 1994. Un nuevo género de Nassauviinae (Asteraceae, Mutiseae) y sus relaciones cladísticas con los géneros afines de la subtribu. Bol. Soc. Argent. Bot. 30: 59-70.

Katinas, L., Pruski, J.F., Sancho, G. \& Tellería, M.C. 2008a. The subfamily Mutisioideae (Asteraceae). Bot. Rev. (Lancaster) 74: 469-716. https://doi.org/10.1007/s12229-008-9016-6

Katinas, L., Crisci, J.V., Schmidt Jabaily, R., Williams, C., Walker, J., Drew, B., Bonifacino, J.M. \& Sytsmá, K.J. 2008b. Evolution of secondary heads in Nassauviinae (Asteraceae, Mutisieae). Amer. J. Bot. 95: 229-240. https://doi.org/10.3732/ajb.95.2.229

Katinas, L., Sancho, G. \& Vitali, M. 2013. A revision of Lophopappus (Asteraceae, Nassauvieae). Phytotaxa 103: 25-45. https://doi.org/10.11646/phytotaxa.103.1.2

Katinas, L., Hernández, M.P., Arambarri, A.M. \& Funk, V.A. 2016. The origin of the bifurcating style in Asteraceae (Compositae). Ann. Bot. (Oxford) 117: 1009-1021. https://doi.org/10.1093/aob/mcw033

Katoh, K., Misawa, K., Kuma, K. \& Miyata, T. 2002. MAFFT: A novel method for rapid multiple sequence alignment based on fast Fourier transform. Nucl. Acids Res. 30: 3059-3066. https://doi.org/110.1093/nar/gkf436

Kim, K.J.\& Jansen, R.K. 1995. $n d h F$ sequence evolution and the major clades in the sunflower family. Proc. Natl. Acad. Sci. U.S.A. 92: 10379-10383. https://doi.org/10.1073/pnas.92.22.10379

Luebert, F. \& Pliscoff, P. 2006. Sinopsis bioclimática y vegetacional de Chile. Chile: Editorial Universitaria.

Luebert, F., Wen, J. \& Dillon, M.O. 2009. Systematic placement 
and biogeographical relationships of the monotypic genera Gypothamnium and Oxyphyllum (Asteraceae: Mutisioideae) from the Atacama Desert. Bot. J. Linn. Soc. 159: 32-51. https://doi.org/110.1111/j.1095-8339.2008.00926.x

Mau, B., Newton, M.A. \& Larget, B. 1999. Bayesıan phylogenetic inference via Markov chain Monte Carlo methods. Biometrics 55: 1-12. https://doi.org/10.1111/j.0006-341X.1999.00001.x

McNeill, J., Barrie, F.R., Buck, W.R., Demoulin, V., Greuter, W., Hawksworth, D.L., Herendeen, P.S., Knapp, S., Marhold, K., Prado, J., Prud'homme Van Reine, W.F., Smith, G.F., Wiersema, J.H. \& Turland, N.J. (eds.) 2012. International Code of Botanical Nomenclature for algae, fungi, and plants (Melbourne Code): Adopted by the Eighteenth International Botanical Congress Melbourne, Australia, July 2011. Regnum Vegetabile 154. Königstein: Koeltz Scientific Books.

Miller, H.S. 1970. The herbarium of Aylmer Bourke Lambert: Notes on its acquisition, dispersal, and present whereabouts. Taxon 19: 489-553. https://doi.org/10.2307/1218947

Miller, M.A., Pfeiffer, W. \& Schwartz, T. 2010. Creating the CIPRES Science Gateway for inference of large phylogenetic trees. Pp. 45-52 in: Proceedings of the Gateway Computing Environments Workshop (GCE), New Orleans, Louisiana, 14 Nov 2010. Piscataway: IEEE. https://doi.org/10.1109/GCE.2010.5676129

Moreira-Muñoz, A., Morales, V. \& Muñoz-Schick, M. 2012. Actualización sistemática y distribución geográfica de Mutisioideae (Asteraceae) de Chile. Gayana Bot. 69: 9-29. https://doi.org/10.4067/S0717-66432012000100003

Nguyen, L.T., Schmidt, H.A., von Haeseler, A. \& Minh, B.Q. 2015. IQ-TREE: A fast and effective stochastic algorithm for estimating maximum-likelihood phylogenies. Molec. Biol. Evol. 32: 268-274. https://doi.org/10.1093/molbev/msu300

Noltie, H.J. 2010. A commentary on the new taxa described in The Botany of Captain Beechey's Voyage by W.J. Hooker and G.A. Walker-Arnott. Edinburgh: Royal Botanic Garden.

Olmstead, R.G. \& Sweere, J.A. 1994. Combining data in phylogenetic systematics: An empirical approach using three molecular data sets in the Solanaceae. Syst. Biol. 43: 467-481. https://doi.org/10.1093/sysbio/43.4.467

Panero, J.L. \& Funk, V.A. 2008. The value of sampling anomalous taxa in phylogenetic studies: Major clades of the Asteraceae revealed. Molec. Phylogen. Evol. 47: 757-782. https://doi.org/10.1016/j.ympev.2008.02.011

Panero, J.L., Freire, S.E., Ariza Espinar, L., Crozier, B.S., Barboza, G.E. \& Cantero, J.J. 2014. Resolution of deep nodes yields an improved backbone phylogeny and a new basal lineage to study early evolution of Asteraceae. Molec. Phylogen. Evol. 80: 43-53. https://doi.org/10.1016/j.ympev.2014.07.012

Pelser, P.B., Kennedy, A.H., Tepe, E.J., Shidler, J.B., Nordenstam, B., Kadereit, J.W. \& Watson, L.E. 2010. Patterns and causes of incongruence between plastid and nuclear Senecioneae (Asteraceae) phylogenies. Amer. J. Bot. 97: 856-873. https://doi.org/10.3732/ajb.0900287

Punt, W., Blackmore, S., Nilsson, S. \& Thomas, L. 1994. Glossary of pollen and spore terminology. Utrecht: LPP Foundation.

Ramayya, N. 1962. Studies on the trichomes of some Compositae. I. General structure. Bull. Bot. Surv. India 4: 177-188.

Ronquist, F. \& Huelsenbeck, J.P. 2003. MrBayes 3: Bayesian phylogenetic inference under mixed models. Bioinformatics 19: 1572-1574. https://doi.org/10.1093/bioinformatics/btg180
Sancho, G., Katinas, L. \& Plos, A. 2014. Is morphology supporting a monophyletic Proustia Lag., (Nassauvieae, Asteraceae). Pl. Syst. Evol. 300: 2265-2276. https://doi.org/10.1007/s00606-014-1052-6

Sancho, G., de Lange, P.J., Donato, M., Barkla, J. \& Wagstaff, S.J. 2015. Late Cenozoic diversification of the austral genus Lagenophora Cass. (Astereae, Asteraceae). Bot. J. Linn. Soc. 177: 78-95. https://doi.org/110.1111/boj.12224

Shaw, J., Lickey, E.B., Schilling, E.E.\& Small, R.L. 2007. Comparison of whole chloroplast genome sequences to choose noncoding regions for phylogenetic studies in angiosperms: The tortoise and the hare III. Amer. J. Bot. 94: 275-288. https://doi.org/10.3732/ajb.94.3.275

Shimodaira, H. 2002. An approximately unbiased test of phylogenetic tree selection. Syst. Biol. 51: 492-508. https://doi.org/10.1080/10635150290069913

Simpson, B.B., Arroyo, M.T.K., Sipe, S., Días de Moraes, M. \& McDill, J. 2009. Phylogeny and evolution of Perezia (Asteraceae: Mutisieae: Nassauviinae). J. Syst. Evol. 47: 431-443. https://doi.org/10.1111/j.1759-6831.2009.00039.x

Stamatakis, A., Hoover, P. \& Rougemont. J. 2008. A rapid bootstrap algorithm for the RAxML web servers. Syst. Biol. 57: 758-771. https://doi.org/10.1080\%2F10635150802429642

Stöver, B.C. \& Müller, K.F. 2010. TreeGraph 2: Combining and visualizing evidence from different phylogenetic analyses. B. M. C. Bioinformatics 11: 7. https://doi.org/10.1186/1471-2105-11-7

Stuessy, T.F. \& Urtubey, E. 2006. Phylogenetic implications of corolla morphology in subfamily Barnadesioideae (Asteraceae). Flora 201: 340-352. https://doi.org/10.1016/j.flora.2005.07.009

Stuessy, T.F., Sang, T. \& DeVore, M.L. 1996. Phylogeny and biogeography of the subfamily Barnadesioideae with implications for early evolution of Compositae. Pp. 463-490 in: Hind, D.J.N., Jeffrey, C. \& Pope, G.V. (eds.), Proceedings of the International Compositae Conference, 1994, Kew, vol. 1, Systematics. Kew: Royal Botanic Gardens.

Taberlet, P., Gielly, L., Pautou, G. \& Bouvet. J. 1991. Universal primers for amplification of three non-coding regions of chloroplast DNA. Pl. Molec. Biol. 17: 1105-1109.

Tellería, M.C., Urtubey, E. \& Katinas, L. 2003. Proustia and Lophopappus (Asteraceae, Mutisieae): Generic and subtribal relationships based on pollen morphology. Rev. Palaeobot. Palynol. 123: 237-246.

Turner, B.L. 1993. Berylsimpsonia (Asteraceae: Mutisieae), a new genus of the Greater Antilles. Phytologia 74: 349-355.

Vences, M., Guayasamin, J.M., Miralles, A. \& de la Riva, I. 2013. To name or not to name: Criteria to promote economy of change in Linnaean classification schemes. Zootaxa 3636: 201-244. https://doi.org/10.11646/zootaxa.3636.2.1

White, T.J., Bruns, T., Lee, S. \& Taylor, J. 1990. Amplification and direct sequencing of fungal ribosomal RNA genes for phylogenetics. Pp. 315-322 in: Innis, M.A., Gelfand, D.H., Sninsky, J.J. \& White, T.J. (eds.), PCR protocols: A guide to methods and applications. New York: Academic Press.

Willis, K.J. (ed.) 2017. State of the World's plants 2017: Report. Kew: Royal Botanic Gardens.

Zuloaga, F.O., Morrone, O. \& Belgrano, M.J. 2008. Catálogo de las plantas vasculares del Cono Sur (Argentina, Sur de Brasil, Chile, Paraguay y Uruguay). Monogr. Syst. Bot. Missouri Bot. Gard. 107: $1-3348$. 
Appendix 1. Voucher information and GenBank accession numbers for taxa used in the present study.

Species, country, voucher specimen and/or reference and GenBank accession numbers for ETS, ITS, $\operatorname{trn} K$ - $m a t K, n d h F, \operatorname{trn} L$-rpl32, $\operatorname{trn} L$-trnF, respectively. Newly generated sequences are indicated by an asterisk $\left(^{*}\right)$ and missing sequences are indicated by a dash $(-)$.

Acourtia coulteri (A.Gray) Reveal \& R.M.King: Mexico, Tamaulipas, Iltis 30748 (TEX), Simpson \& al. (2009), -, FJ979680, -, -, -, -. Acourtia turbinata (La Llave \& Lex.) DC.: Mexico, Panero 2891 (TEX), Panero \& Funk (2008), -,-, EU385317, EU385126, -, EU385032. Adenocaulon chilense Less.: Chile, Reg. Aysén, Luebert \& Daniłowicz-Luebert 3226 (BONN), MG553831*, MG553794*, MG553765*, MG553685*, MG553876*, MG553725*. Berylsimpsonia sp.: República Dominicana, P. Escondido, Clase 7675 (B), MG553825*, MG553791*, MG553759*, MG553679*, MG553870*, MG553719*. Berylsimpsonia vanillosma (C.Wright) B.L.Turner: Puerto Rico, Adjuntas, Axelrod \& Turquist 13767 (UPRRP), -, MG553775*, -, MG553663*, MG553852*, MG553703*; Puerto Rico, King \& Proctor 10601 (US), -, MG553774*, MG553736*,-,-, MG553696*. Calopappus acerosus Meyen: Chile, Los Andes, Panero \& Crozier 8457 (TEX), Panero \& al. (2014), -, FJ979685, KM192112, KM192101, FJ979735, KM191902. Chaetanthera sp.: Chile, Reg. Atacama, Moreira 1736 (SGO), MG553835*, MG553798*, MG553768*, MG553688*, MG553880*, MG553729*. Chuquiraga jussieui J.F.Gmel.: Peru, Lambayeque, Weigend \& al. 9677 (BONN), MG553840*, MG553801*, MG553773*, MG553693*, MG553885*, KY458442. Dolichlasium lagascae D.Don: Argentina, Mendoza, Bonifacino 1635 (LP), Simon 811 (US), Panero \& Funk (2008), Katinas \& al. (2008), -, EF530259, EU385347, EU385155, -, EU385062. Gerbera sp.: Vincent 13223 (MU), Pelser \& al. (2010), GU818171, GU818551, GU817629+GU817463, GU817862, -, GU817955+GU817941. Gypothamnium pinifolium Phil.: Chile, Reg. Antofagasta, Luebert \& García 2762/1156 (SGO), -, EU729342, MG553744*, EU729346, MG553853*, EU729338. Holocheilus brasiliensis (L.) Cabrera: Uruguay, Maldonado, Bonifacino 1203 (MVFA), Katinas \& al. (2008), -, EF530247, -, -, -, -. Jungia floribunda Less.: Uruguay, Cerro Largo, Bonifacino 1306 (MVFA), Katinas \& al. (2008), -, EF530233,-,-,-,-. Jungia rugosa Less.: Peru, Cajamarca, Henning \& Schneider 166 (B), -, MG553778*, ,,,---- . Jungia polita Griseb.: Argentina, Simon 292 (US), Panero \& Funk (2008), -, -, EU385370, EU385178, -, EU385084. Leucheria tomentosa (Less.) Crisci: Chile, Reg. Valparaíso, Moreira \& Luebert 1237 (SGO), MG553813*, MG553776*,-,-,-,- Leucheria thermarum (Phil.) Phil.: Chile, Simon 383 (US), Panero \& Funk (2008), -, -, EU385371, EU385179, -, EU385085. Lophopappus cuneatus R.E.Fr.; Peru, Moquegua, Weigend \& al. 9523 (BONN), MG553838*,-, MG553771*, MG553691*, MG553883*, MG553732*. Lophopappus foliosus Rusby: Chile, Reg. Arica y Parinacota, Moreira 1962 (SGO), MG553823*, MG553790*, MG553757*, MG553677*, MG553868*, MG553717*; Chile, Reg. Arica y Parinacota, Moreira \& Luebert 2414 (SGO), MG553839*, MG553800*, MG553772*, MG553692*, MG553884*, MG553733*. Lophopappus tarapacanus (Phil.) Cabrera: Chile, Reg. Arica y Parinacota, Moreira 1947 (SGO), MG553824*,-, MG553758*, MG553678*, MG553869*, MG553718*; Chile, Reg. Arica y Parinacota, Moreira \& Luebert 2371 (BONN), MG553837*,-, MG553770*, MG553690*, MG553882*, MG553731*; Chile, Moreira \& al. 2005 (SGO), MG553803*,-, MG553734*, MG553653*, MG553842*, MG553694*. Moscharia pinnatifida Ruiz \& Pav.: Chile, Reg. Coquimbo, Luebert \& Hilger 3148 (BONN), MG553832*, MG553795*, -, -, MG553877*, MG553726*. Mutisia spinosa Ruiz \& Pav.: Chile, Reg. Aysén, Luebert \& Daniłowicz-Luebert 3229 (BONN), MG553836*, MG553799*, MG553769*, MG553689*, MG553881*, MG553730*. Nassauvia axillaris (Lag. ex Spreng.) D.Don, Argentina, Mendoza, Bonifacino 1610 (LP), Katinas \& al. (2008), -, EF530232,-,-, -, - Nassauvia pygmaea (Cass.) Hook.f.: Argentina, Bonifacino 179 (US), Panero \& Funk (2008), -, -, EU385377, EU385186, -, EU385092. Oxyphyllum ulicinum Phil.: Chile, Reg. Atacama, Luebert \& García 2829/1223 (SGO), MG553812*, EU729344, MG553745*, EU729348, MG553854*, EU729340. Pachylaena atriplicifolia D.Don ex Hook. \& Arn.: Argentina, Bonifacino 1602 (LP), Simon 684 (US), Panero \& Funk (2008), Katinas \& al. (2008), -, EF530250, EU385383, EU385192, -, EU385098. Perezia lanigera Hook. \& Arn.: Argentina, Santa Cruz, Albert 8-XI-2006-2 (TEX), Simpson \& al. (2009), -, FJ979678, -, -, -, -. Perezia nutans Less.: Chile, Wen 7472 (F), Simpson \& al. (2009), -, FJ979671, -, -, -, -. Perezia pinnatifida (Bonpl.) Wedd.: Chile, Reg. Arica y Parinacota, Moreira \& Luebert AM2422 (SGO), MG553834*, MG553797*, MG553767*, MG553687*, MG553879*, MG553728*. Perezia purpurata Wedd.: Beck 31111 (LPB), Simon 594 (US), Panero \& Funk (2008); Simpson \& al. (2009), -, -, EU385385, EU385194, FJ979693, EU385100. Plazia daphnoides Wedd.: Chile, Reg. Arica y Parinacota, Trivelli s.n. (SGO), MG553822*, MG553789*, MG553756*, MG553676*, MG553867*, MG553716* Polyachyrus fuscus (Meyen) Walp.: Chile, Reg. Antofagasta, Moreira \& Luebert 1219 (SGO), MG553814*, MG553777*, MG553746*, MG553664*, MG553855*, MG553704*. Proustia cuneifolia f. cinerea (Phil.) Fabris: Chile, Reg. Santiago, Luebert \& Moreira 3038 (SGO), -,-,-, MG553666*, MG553857*, MG553706*; Chile, Reg. Valparaíso, Hichins s.n. (SGO), MG553820*, MG553787*, MG553755*, MG553675*, MG553866*, MG553715*; Chile, Reg. Valparaíso, Luebert \& Danilowicz 3029 (SGO), MG553816*, MG553780*, MG553748*, MG553668*, MG553859*, MG553708*; Chile, Moreira 2139 (SGO), MG553804*,-, MG553735*, MG553654*, MG553843*, MG553695*. Proustia cuneifolia f. cuneifolia D.Don: Bolivia, Tarija, Beck \& al. 23720 (S), MG553830*,-, MG553764*, MG553684*, MG553875*, MG553724*; Chile, Reg. Santiago, Sancho \& al. 262 (LP),-,-, MG553743*, MG553662*, MG553851*, MG553702*; Chile, Reg. Valparaíso, Luebert \& Danitowicz 3028 (SGO), MG553817*, MG553781*, MG553749*, MG553669*, MG553860*, MG553709*; Chile, Moreira 2138 (SGO), MG553809*, -, MG553740*, MG553659*, MG553848*, -; Peru, Moquegua, Weigend \& al. 9517 (BONN), MG553828*,-, MG553762*, MG553682*, MG553873*, MG553722*; Peru, Moquegua, Weigend \& al. 9518 (BONN), MG553829*,-, MG553763*, MG553683*, MG553874*, MG553723*. Proustia cuneifolia f. mendocina (Phil.) Fabris: Argentina, Córdoba, Gutiérrez \& al. 1207 (LP), MG553805*,-,-, MG553655*, MG553844*, MG553697*; Argentina, La Rioja, Bonifacino 1547 (LP), Katinas \& al. (2008), -, EF530244, -, -, -, -; Argentina, San Juan, Bonifacino 1593 (LP), Katinas \& al. (2008), MG553802*, EF530251, -, -, MG553841*, EF530297. Proustia cuneifolia var. mollis (Kuntze) Cabrera: Argentina, Jujuy, Sancho \& Viera 252A (LP), MG553808*,-, MG553739*, MG553658*, MG553847*, MG553699*; Argentina, Salta, Sancho \& al. 243 (LP), MG553806*,-, MG553737*, MG553656*, MG553845*, MG553698*; Argentina, Salta, Sancho \& al. 247 (LP), MG553807*,-, MG553738*, MG553657*, MG553846*,-.Proustia cuneifolia f. tipia (Phil.) Fabris: Chile, Reg. Antofagasta, Moreira \& Luebert 1203 (SGO), -, MG553784*, MG553752*, MG553672*, MG553863*, MG553712*; Chile, Reg. Antofagasta, Romero \& Medina V21 (EIF),-, MG553785*, MG553753*, MG553673*, MG553864*, MG553713*; Chile, Reg. Antofagasta, Romero \& Medina V09 (EIF), MG553819*, MG553786*, MG553754*, MG553674*, MG553865*, MG553714*. Proustia ilicifolia f. ilicifolia Hook. \& Arn.: Chile, Reg. Coquimbo, Luebert \& Hilger 3157 (BONN), MG553826*, MG553792*, MG553760*, MG553680*, MG553871*, MG553720*; Chile, Reg. Coquimbo, Teillier 6589 (BONN), -, MG553782*, MG553750*, MG553670*, MG553861*, MG553710*. Proustia ilicifolia f. baccharoides (D.Don) Fabris: Chile, Reg. Coquimbo, Luebert \& Hilger 3151 (BONN), MG553827*, MG553793*, MG553761*, MG553681*, MG553872*, MG553721*; Chile, Reg. Santiago, Luebert \& Moreira 3042 (SGO), -, -, -, MG553665*, MG553856*, MG553705*; Chile, Luebert 3053 (SGO), MG553818*, MG553783*, MG553751*, MG553671*, MG553862*, MG553711*; Chile, Moreira 2140 (SGO), MG553810*,-, MG553741*, MG553660*, MG553849*, MG553700*. Proustia pyrifolia DC.: Chile, Reg. O’Higgins, Sancho \& al. 285 (LP), MG553811*,-, MG553742*, MG553661*, MG553850*, MG553701*; Chile, Reg. Santiago, Luebert \& Moreira 3037 (SGO), MG553815*, MG553779*, MG553747*, MG553667*, MG553858*, MG553707*. Triptilion capillatum Hook. \& Arn.: Chile, Reg. Metropolitana, Bonifacino 1336 (LP), Katinas \& al. (2008), -, EF530222,-,-,-,-. Trixis cacalioides (Kunth) D.Don: Chile, Reg. Arica y Parinacota, Moreira \& Luebert 2364 (SGO), MG553833*, MG553796*, MG553766*, MG553686*, MG553878*, MG553727*. Trixis divaricata (Kunth) Spreng.: Brazil, Santos 2659 (TEX), Panero \& Funk (2008), -,-, EU385405, EU385214, -, EU385120. Urmenetea atacamensis Phil.: Chile, Reg. Antofagasta, Medina 999 (SGO), MG553821*, MG553788*, - 